\title{
Multifunctional Hybrid Materials Based on Transparent Poly(methyl methacrylate) Reinforced by Lanthanoid Hydroxo Clusters
}

Philip C. Andrews, ${ }^{a}$ David H. Brown, ${ }^{b}$ Benjamin H. Fraser, ${ }^{a}$ Nicole T. Gorham, ${ }^{b}$ Peter C. Junk, ${ }^{a, *}$ Massimiliano Massi, ${ }^{b, *}$ Timothy G. St Pierre, ${ }^{c}$ Brian W. Skelton, ${ }^{d}$ Robert C. Woodward ${ }^{c}$

${ }^{a}$ School of Chemistry, Monash University, Box 23, Clayton 3800, Victoria, Australia

${ }^{b}$ Department of Chemistry, Curtin University, GPO Box U1987, Perth 6845, Western Australia, Australia

${ }^{c}$ School of Physics, University of Western Australia, Stirling Highway, Crawley 6009, Western Australia, Australia

${ }^{d}$ School of Biomedical, Biomolecular and Chemical Sciences, University of Western Australia, Stirling Highway, Crawley 6009, Western Australia, Australia

Corresponding author emails: peter.junk@sci.monash.edu.au, m.massi@curtin.edu.au

Keywords: lanthanoid clusters, reinforced polymers, luminescence, magnetism, hybrid materials

\begin{abstract}
Three pentanuclear lanthanoid hydroxo clusters of composition $\left[\mathrm{Ln}(\mathrm{OH})_{5}(\mathbf{a b z m})_{10}\right]$, where $\mathrm{Ln}$ $=\mathrm{Eu}, \mathrm{Tb}, \mathrm{Ho}$ and $\mathbf{a b z m}=\operatorname{di}(4-$ allyloxy $)$ benzoylmethanide, have been prepared. The structures have been characterised by means of IR, Raman, elemental analyses and X-ray diffraction, showing a pyramidal square-based cluster core. The clusters ( $\mathrm{Tb}$ and $\mathrm{Ho}$ ) exhibit Curie-Weiss Law behaviour, displaying antiferromagnetic ordering at low temperatures. The emission properties of the Eu cluster demonstrate the $\mathbf{a b z m}^{-}$ligand is an efficient antenna ( $\lambda_{\mathrm{ex}}$ $=420 \mathrm{~nm}$ ) only for the sensitisation of Eu luminescence in the visible range, via energy transfer to the ${ }^{5} \mathrm{D}_{0}$ state of the trivalent metal. The clusters have been reacted in the presence of methyl methacrylate and azobisisobutyronitrile to prepare reinforced polymers via radical polymerisation. The obtained materials exhibit swelling upon immersion into organic solvents
\end{abstract}


up to $\approx 110 \%$ of their original size, in agreement with the presence of cluster-crosslinked polymeric chains. Also, no loss of transparency was observed in the preparation of the materials. The characteristic red emission of the Eu cluster in also retained in the polymeric material.

\section{Introduction}

The preparation of inorganic-organic hybrid materials is an extremely active area of scientific research, where interest stems from their many applications in organic electronics and nanotechnology. In particular, the incorporation of inorganic species into transparent polymeric matrices has been recently studied. ${ }^{1}$ These combinations allow new functionalities, including magnetic or optical properties, to be integrated within a polymeric matrix, thereby providing new classes of materials with features derived from both their organic and inorganic components. Materials with such highly tunable properties are attractive for the fabrication of, for example, light emitting, ${ }^{2}$ non-linear optical, ${ }^{3}$ and magnetic information storage devices. ${ }^{4}$ However, the incorporation of inorganic components into a polymer matrix is often a challenging task. Simple dispersion of the inorganic material into the polymer can result in a loss of transparency due to scattering from large particles. ${ }^{5,6}$ As the Rayleigh scattering intensity is proportional to the particle diameter $(d),{ }^{6,7}$ the use of monodispersed nanoparticles could be a possible solution for this problem. ${ }^{8-10}$ Unfortunately, in some cases, phase separation may still occur and nanoparticle aggregation results in larger sized aggregates, again leading to a loss of transparency. ${ }^{6}$ To avoid aggregation, nanoparticle-embedded materials can be generated by in situ polymerisation where the nanoparticles are suspended in a monomer solution prior to polymerisation. Here the particles are coated with specific organic ligands, such as oligomers of the targeted polymeric matrix, or dispersed in the presence of additives such as polyethyleneglycol monooleate. ${ }^{5,7,8,10}$ 
As an alternative to the dispersion method, inorganic species can be directly anchored onto the polymeric chains of the matrix, either through covalent or ionic bonds. ${ }^{11-13}$ This method can avoid particle aggregation, however endowing the surface of the inorganic particles with specific functional groups can be a synthetically challenging. These functionalities must then be able to react with the host monomers during the polymerisation process. This strategy is not only advantageous for the preparation of high quality multifunctional materials, but also improves the mechanical and thermal properties of the material when the inorganic component is able to promote crosslinking, leading to 'reinforced' polymers. ${ }^{1,14-16}$ Several studies report polymeric matrices which have been reinforced with surface modified inorganic clusters such as polyhedral oligomeric silsesquioxanes, ${ }^{11}$ spherosilicates, ${ }^{16}$ oxotitanium and oxozirconium clusters ${ }^{17}$ heterotungstates, ${ }^{11}$ magnetic dodecanuclear manganese oxide clusters, ${ }^{15}$ and recently octahedral rhenium clusters. ${ }^{14}$ In comparison to nanoparticles, inorganic clusters are not affected by polydispersity, they can be prepared and characterised by standard molecular chemistry, and they often can be finely tuned to achieve the desired functional properties. Despite these many examples, there have been no reports of polymeric materials reinforced by oxo/hydroxo clusters of the rare earth elements. This can be attributed to the fact that in comparison to transition and main group clusters, the chemistry of oxo/hydroxo lanthanoid clusters is less developed and more often than not serendipituous. ${ }^{18-20}$ However, it is now possible to rationally design such lanthanoid clusters, ${ }^{21-29}$ and their magnetic and optical properties, arising from the $4 \mathrm{f}$ electrons, make them a very attractive platform of polymer reinforcing. Many lanthanoid compounds have been investigated as single molecule magnets, ${ }^{29}$ and as phosphors with emission ranging from the visible to the infrared. ${ }^{30-32}$

We have therefore investigated the preparation of a series of pentanuclear lanthanoid (Eu, Tb, Ho) hydroxo clusters surrounded by $\beta$-diketonate ligands functionalised with allyloxy groups (denoted abzmH in Figure 1), and have characterised their magnetic and 
optical properties. Furthermore, we have studied the formation of reinforced polymers using these clusters as crosslinking agents. In this respect, this work represents the first example of reactions performed on the outer shell of preformed lanthanoid hydroxo clusters as well as the first example of a lanthanoid cluster reinforced organic polymer.

\section{Results and Discussion}

\section{Synthesis and Characterisation of the Allyl Functionalised Pentanuclear Clusters}

The pentanuclear clusters $\left[\operatorname{Ln}_{5}(\mathrm{OH})_{5}(\mathbf{a b z m})_{10}\right]$ were prepared by heating to reflux a methanol solution of one eq. of a hexahydrated lanthanoid salt $\left[\mathrm{LnCl}_{3}\left(\mathrm{H}_{2} \mathrm{O}\right)_{6}, \mathrm{Ln}=\mathrm{Eu}, \mathrm{Tb}\right.$, Ho] with two eq. of the diketone $\mathbf{a b z m} \mathrm{H}^{33}$ in presence of an excess of triethylamine (Figure 1). As the obtained products are highly soluble in organic solvents, they can be conveniently extracted in toluene and subsequently precipitated by addition of hexane. The pentanuclear nature of the clusters was confirmed by structural X-ray studies, IR spectroscopy and elemental analysis. The lowered frequencies of the carbonyl stretching bands for $\left[\operatorname{Ln}_{5}(\mathrm{OH})_{5}(\mathbf{a b z m})_{10}\right]\left(\approx 1590 \mathrm{~cm}^{-1}\right)$ compared to $\mathbf{a b z m H}\left(1648 \mathrm{~cm}^{-1}\right)$ are indicative of the presence of the $\mathbf{~ a b z m}^{-}$ligands. The vibrations corresponding to the $\mathrm{OH}$ stretching appear at 3597,3624 , and $3609 \mathrm{~cm}^{-1}$ respectively for $\mathrm{Eu}, \mathrm{Tb}$, and Ho. Each of the $\mathrm{OH}$ peaks appears to be split with a shoulder at lower frequencies, which can be ascribed to the presence of two types of $\mathrm{OH}$ ligand in the cluster core ( $\mu_{3}$ - and $\mu_{4}$-coordinated). Also, the relatively high frequencies for these stretching modes indicates no hydrogen bonding, which is confirmed by the X-ray structural data. Luneau and co-workers ${ }^{23}$ have proposed that cluster nuclearity and geometry can be specified through Raman spectroscopy. On that basis, Raman spectra for the

three clusters were measured in the region $200-900 \mathrm{~cm}^{-1}$, the range in which Raman shifts of the Ln-O vibration are likely to be located. The spectra, which are shown in Figure 2, show an almost identical profile, with only minor differences in the shifts and intensities of some peaks. In order to identify the peaks belonging to the Ln-O bonds within the cluster core, the three 
spectra were directly compared with the Raman spectrum of the abzmH ligand. $\uparrow$ From the latter, it is evident that the four bands at about $220,620,690$, and $830 \mathrm{~cm}^{-1}$ are representative of the ligand. This set of bands appears in the spectra of both the ligand and the clusters; providing further confirmation of the proposed cluster structures in terms of peripheral shell composition. The remaining bands in the three cluster spectra, i.e. the weaker broad bands at 330 and $530 \mathrm{~cm}^{-1}$ and the more intense sharp ones at 410,760 , and $880 \mathrm{~cm}^{-1}$, are associated with vibrational modes of the Ln-O bonds. The cluster spectra all show similar features to that observed for the analogous pentanuclear Eu hydroxo cluster, obtained previously by Luneau and co-workers using the dibenzoylmethanide ligand. ${ }^{23}$ As such, the Raman spectra support the pentanuclear nature of the allyloxy-functionalised dibenzoylmethanide clusters reported in this work.

The relative stability in solution of hydroxo clusters was determined in previous works, showing that the cores were relatively stable in polar organic solvents and unstable in water. ${ }^{34}$ As certain applications in materials science often require stability in the presence of oxygen and humidity, the stability of the clusters in the solid state was evaluated. Periodic analysis over a two year period on bulk samples of the three $\left[\mathrm{Ln}_{5}(\mathrm{OH})_{5}(\mathbf{a b z m})_{10}\right]$ clusters always gave consistent IR, Raman, and elemental data. Therefore, it would appear that they are completely stable to atmospheric moisture and oxygen for prolonged periods of time.

\section{X-ray Structural Determinations}

The crystal structure of $\left[\mathrm{Eu}_{5}(\mathrm{OH})_{5}(\mathbf{a b z m})_{10}\right]$ is shown in Figure 1. The compound is isomorphous with the previously reported pentanuclear hydroxo clusters, ${ }^{22,23,25,29}$ where the core is composed of a square-based pyramid of Eu cations, linked together on each side by a $\mu_{3}$-coordinated $\mathrm{OH}$ ligand, and at the base by a $\mu_{4}$-coordinated $\mathrm{OH}$ ligand. The structures of the analogous $\mathrm{Tb}$ and Ho complexes are essentially identical, with the only significant differences being in the Ln-O bonds due to the lanthanoid contraction effect. $\uparrow$ The crystal 
structures of the clusters show no evidence of hydrogen bonding or interactions involving the $\mathrm{H}$ atoms of the hydroxo ligands, which is consistent with the high frequencies of the $\mathrm{OH}$ stretching vibrations in the IR spectra. Along with previously reported ethoxy-functionalised dibenzoylmethanide pentanuclear lanthanoid clusters, ${ }^{25}$ these structures confirm that it is possible to include different functional groups of a relatively small size in the outer shell without affecting the capability of the diketonate ligand to template the formation of the cluster core.

\section{Luminescent and Magnetic Properties of the Pentanuclear Clusters}

The emission profile of $\left[\mathrm{Eu}_{5}(\mathrm{OH})_{5}(\mathbf{a b z m})_{10}\right]$ was measured at room temperature (Figure 3), revealing the typical red emission of the trivalent Eu cation upon excitation at $\lambda_{\mathrm{ex}}=$ $420 \mathrm{~nm} .{ }^{35}$ In the $500-700 \mathrm{~nm}$ region, the spectrum shows emission peaks corresponding to ${ }^{5} \mathrm{D}_{0} \rightarrow{ }^{7} \mathrm{~F}_{\mathrm{J}}$ with $\mathrm{J}=0-4$. The most intense transition is the electric-dipole ${ }^{5} \mathrm{D}_{0} \rightarrow{ }^{7} \mathrm{~F}_{2}$ at $611 \mathrm{~nm}$, whereas all the other peaks have relative low intensity. The ratio between $I\left({ }^{5} \mathrm{D}_{0} \rightarrow{ }^{7} \mathrm{~F}_{2}\right)$ and the intensity of the magnetic-dipole allowed transition ${ }^{5} \mathrm{D}_{0} \rightarrow{ }^{7} \mathrm{~F}_{1}$ is quite large, about 16 for $\left[\mathrm{Eu}_{5}(\mathrm{OH})_{5}(\mathbf{a b z m})_{10}\right]$, suggesting emission from Eu cations in low symmetry sites. ${ }^{23}$ The broad peak at $578 \mathrm{~nm}$, corresponding to the forbidden ${ }^{5} \mathrm{D}_{0} \rightarrow{ }^{7} \mathrm{~F}_{0}$ transition, indicates that in the cluster core not all the five emitting $\mathrm{Eu}^{3+}$ centres are of identical nature. ${ }^{23}$ A comparison of the photophysical data with previously reported pentanuclear Eu clusters confirms that emission spectral profiles, coupled with Raman spectroscopy, are useful tools for the identification of specific nuclearity and geometry of cluster cores, especially when crystallographic determinations are not available. ${ }^{23}\left[\mathrm{~Tb}_{5}(\mathrm{OH})_{5}(\mathbf{a b z m})_{10}\right]$ did not show any typical greencentred emission, which is ascribed to an inefficient antenna sensitisation from the $\mathbf{a b z m}^{-}$ ligand. The triplet excited state of $\mathbf{~ a b z m}^{-}$is likely to be too low in energy, compared to the analogous dibenzoylmethanide ligand, to populate the ${ }^{5} \mathrm{D}_{4}$ excited state of $\mathrm{Tb}^{3+}$. In fact, 
considering that the singlet excited state of the $\mathbf{~ a b z m}^{-}$ligand lies at an energy of $23,810 \mathrm{~cm}^{-1}$, the energy transfer to the ${ }^{5} \mathrm{D}_{4}$ state of $\mathrm{Tb}^{3+}$ at $20,500 \mathrm{~cm}^{-1}$ is likely to be inefficient. ${ }^{35}$

Both $\left[\mathrm{Tb}_{5}(\mathrm{OH})_{5}(\mathbf{a b z m})_{10}\right]$ and $\left[\mathrm{Ho}_{5}(\mathrm{OH})_{5}(\mathbf{a b z m})_{10}\right]$ exhibit Curie-Weiss Law behaviour (Figure 4). The effective magnetic moment corresponds closely to the expected values for isolated ions $\left(9.41 \mu_{\mathrm{B}}\right.$ per atom for the Tb complex and $10.37 \mu_{\mathrm{B}}$ per atom for the Ho complex). Both the $\mathrm{Tb}$ and Ho clusters display antiferromagnetic ordering at low temperatures, with a Néel temperature of 2.3 and $4.6 \mathrm{~K}$ respectively. The ordering temperature values are consistent with dipolar coupling of spins. However the magnetic behaviour of $\left[\mathrm{Eu}_{5}(\mathrm{OH})_{5}(\mathbf{a b z m})_{10}\right]$, shown in Figure 5, is significantly more complex but is consistent with the behaviour of previously reported trivalent Eu compounds. ${ }^{36}$

\section{Preparation and Characterisation Cluster-Reinforced PMMA}

Methyl methacrylate (MMA) was chosen as the monomer with which to investigate the preparation of the cluster reinforced polymers. Four samples of poly(methyl methacrylate) (PMMA) were prepared by radical polymerisation in the presence of azobisisobutyronitrile (AIBN), using either the abzmH ligand $\left(\mathrm{PMMA}^{\mathrm{LH}}\right)$ or the $\left[\mathrm{Ln}_{5}(\mathrm{OH})_{5}(\mathbf{a b z m})_{10}\right]$ cluster $\left(\mathrm{PMMA}^{\mathrm{Ln}}\right)$ as a crosslinking agent. Table 1 summarises the molar composition of each of the four materials. In order to obtain polymer samples that were transparent and uniform, without the appearance of bubbles and cracks, a modified procedure based on that reported by Schubert et al. was followed. ${ }^{37}$ Firstly, both AIBN and $\left[\operatorname{Ln}_{5}(\mathrm{OH})_{5}(\mathbf{a b z m})_{10}\right]$ were dissolved in neat MMA. The advantage of using $\left[\mathrm{Ln}_{5}(\mathrm{OH})_{5}(\mathbf{a b z m})_{10}\right]$ as a crosslinker is the fact that the cluster species are highly soluble in organic solvents, including MMA. Therefore, compared to other inorganic crosslinkers, phase segregation issues and loss of transparency are easily avoided over a wide concentration range of $\left[\operatorname{Ln}_{5}(\mathrm{OH})_{5}(\mathbf{a b z m})_{10}\right]$ in MMA. This can be efficiently exploited for the preparation of materials with diverse thermal and mechanical properties. Radical polymerisation was initiated by heating the solution in a capped vial at 
$90{ }^{\circ} \mathrm{C}$ for three minutes, followed by immediate cooling of the solution in an ice-water bath. The molar amount of AIBN is crucial for this step, it was observed that for AIBN quantities higher than $0.6 \%$ a violent exothermic reaction quickly occurs after about one minute of heating. Following the radical initiation stage, the mixture is maintained at $45{ }^{\circ} \mathrm{C}$ overnight and at then at $55^{\circ} \mathrm{C}$ for a further 24 hours. During the latter stage, gelation of the solution was observed. To complete the polymerisation, the thickened gel was then maintained at $75^{\circ} \mathrm{C}$ for another day, after which the gel became a hardened solid. Lastly, to minimise the amount of unreacted MMA, the samples were heated at $120^{\circ} \mathrm{C}$ for $3-5$ hours. Once the heating process was completed, the samples were removed from the vials, soaked in toluene and dried under reduced pressure for two days to remove any unreacted monomer.

To demonstrate the incorporation of $\left[\mathrm{Ln}_{5}(\mathrm{OH})_{5}(\mathbf{a b z m})_{10}\right]$ into the polymer structure, resulting in effective crosslinking, a swelling experiment was performed. The swelling behaviour was compared to a blank material obtained via radical polymerisation, obtained under the exact same conditions but without any crosslinking agent. Sections of PMMA ${ }^{\mathrm{LH}}$ and $\mathrm{PMMA}^{\mathrm{Ln}}$ (cylinders of $10 \mathrm{~mm}$ diameter and about $10 \mathrm{~mm}$ thickness) were cut and immersed for 48 hours in $\mathrm{CH}_{2} \mathrm{Cl}_{2}$. After this time, the sections were removed from the solvent and their diameter immediately measured. The four samples exhibited a similar swelling behaviour, approximately retaining their original shape with dimensions isotropically increased by about $110-120 \%$. The swelling process proved to be reversible, and similar behaviour, albeit with a different swelling capacity, was observed when the samples were immersed in toluene. By contrast, when the uncrosslinked PMMA was immersed in $\mathrm{CH}_{2} \mathrm{Cl}_{2}$, the material expanded forming a liquid organogel losing its original shape. The swelling behaviour undoubtedly demonstrates the effective crosslinking promoted by either the abzmH ligand or the $\left[\operatorname{Ln}_{5}(\mathrm{OH})_{5}(\mathbf{a b z m})_{10}\right]$ clusters. ${ }^{17}$ No loss of transparency or phase segregation was detected in either the polymerisation or swelling stage for any of the cluster-crosslinker PMMA samples. However, the $\mathrm{CH}_{2} \mathrm{Cl}_{2}$ swollen PMMA ${ }^{\mathrm{LH}}$ was weak and cracked during a 
subsequent drying process. In comparison, none of the $\mathrm{PMMA}^{\mathrm{Ln}}$ samples exhibited any cracking during solvent removal. Figure 6 shows a picture of the PMMA ${ }^{\mathrm{LH}}$ and $\mathrm{PMMA}^{\mathrm{Ln}}$ after removal of $\mathrm{CH}_{2} \mathrm{Cl}_{2}$ from the swollen materials.

Raman spectra of PMMA, PMMA ${ }^{\mathrm{LH}}$, and PMMA ${ }^{\mathrm{Ln}}$ are very similar due to the low molar amount of crosslinker. Therefore, the emission properties of $\mathrm{PMMA}^{\mathrm{Eu}}$ were recorded as a method to investigate the stability of the clusters to the radical polymerisation conditions. The PMMA ${ }^{\mathrm{Eu}}$ sample was placed in the cuvette holder of the spectrophotometer, in front of both the excitation and emission slits. The spectrum, shown in Figure 6, was recorded using $\lambda_{\mathrm{ex}}=420 \mathrm{~nm}$. The emission profile shows the typical trivalent Eu peaks at 579, 592, and 613 $\mathrm{nm}$, corresponding to the ${ }^{5} \mathrm{D}_{0} \rightarrow{ }^{7} \mathrm{~F}_{\mathrm{J}}$ with $\mathrm{J}=0,1,2$ transitions. The ${ }^{5} \mathrm{D}_{0} \rightarrow{ }^{7} \mathrm{~F}_{3}$ and ${ }^{5} \mathrm{D}_{0} \rightarrow{ }^{7} \mathrm{~F}_{4}$ transitions have a very low intensity. Compared to the emission spectrum of pure $\left[\mathrm{Eu}_{5}(\mathrm{OH})_{5}(\mathbf{a b z m})_{10}\right]$, the peaks are slightly broadened, and a slight decrease in intensity for the ${ }^{5} \mathrm{D}_{0} \rightarrow{ }^{7} \mathrm{~F}_{2}$ transition is observed. However, the broad nature of the forbidden ${ }^{5} \mathrm{D}_{0} \rightarrow{ }^{7} \mathrm{~F}_{0}$ peak is retained and the $I\left({ }^{5} \mathrm{D}_{0} \rightarrow{ }^{7} \mathrm{~F}_{2}\right) / I\left({ }^{5} \mathrm{D}_{0} \rightarrow{ }^{7} \mathrm{~F}_{1}\right)$ is still large, again indicating emission from Eu centres with low symmetry. This broadening effect is most likely a consequence of the different degrees of covalent linking to individual PMMA chains that each $\left[\mathrm{Eu}_{5}(\mathrm{OH})_{5}(\mathbf{a b z m})_{10}\right]$ undergoes during the polymerisation step, which in turn leads to small differences in the crystal field parameters of the Eu centres. In fact, broadening effects due to small differences in the coordination environment of trivalent lanthanoid compounds have been previously reported in phosphate glasses. ${ }^{38}$ Spectra recorded at $\lambda_{\mathrm{ex}}>440 \mathrm{~nm}$ did not show any red emission, indicating that even in the polymeric matrix the emission of the Eu centres occurs via antenna effect from the triplet excited state of the $\mathbf{a b z m}^{-}$ligand. Lowering the $\lambda_{\text {ex }}$ below $390 \mathrm{~nm}$ causes a decreased intensity in the Eu emission and the appearance of a broad peak around $450-500 \mathrm{~nm}$, which is attributed to blue emission from the PMMA chains. $^{[9 a]}$ 


\section{Conclusions}

In conclusion, by reacting bis para allyloxy functionalized dibenzoylmethane with hydrated lanthanoid chlorides $(\mathrm{Eu}, \mathrm{Tb}, \mathrm{Ho})$, three pentanuclear hydroxo clusters have been prepared and characterized using spectroscopic and X-ray diffraction techniques. The magnetic and luminescent properties of the clusters have also been investigated. Only the Eu cluster exhibit emission in the visible spectrum, demonstrating an efficient energy transfer from the outer shell of ligands to the ${ }^{5} \mathrm{D}_{0}$ state of $\mathrm{Eu}^{3+}$. The allyl groups on the periphery of the clusters have been exploited to prepare reinforced polymeric matrices based on PMMA. The polymerization is carried out by reacting the monomer in presence of a small amount of hydroxo cluster and a radical initiator, AIBN in this case. The swelling properties of the obtained materials undoubtedly demonstrate the clusters efficiently acts as crosslinking agents. Moreover, the retained red emission in the case of the Eu cluster suggests that the cluster structure remains intact while being incorporated in the solid material. This work represent the first example of application of lanthanoid hydroxo clusters in the preparation of reinforced polymers. The methodology offers the advantage of preparing transparent polymers, due to the high solubility of the clusters in the neat monomer, thus avoiding unwanted phase segregation leading to a loss of transparency. The functional properties of the inorganic crosslinker can also be effectively transferred into the polymeric matrix, as demonstrated in the case of light emission. The recent advances in the chemistry of lanthanoid clusters, which also allow for the design and synthesis of defined geometries and hence fine tuning of optical and magnetic properties, mean this class of compounds represents a novel platform in the exploration of functionalized hybrid inorganic-organic materials.

\section{Experimental Section}

Materials and Methods: All the solvents and reagents were obtained from Sigma Aldrich and used as received without any further purification. All the reactions were carried out under 
aerobic conditions. The ligand abzmH was prepared according to previously published procedures. ${ }^{33}$ IR spectra were recorded on solid samples using a diamond ATR Perkin Elmer Spectrum 100 FT-IR. Elemental analyses were performed by the University of Otago (Dunedin, New Zealand) on the desolvated bulk materials. Raman spectra were measured with a FT-Raman Bruker RFS100, using a Nd:YAG laser source (1064 nm excitation wavelength, $0.75 \mathrm{~W}$ laser power) and a liquid nitrogen cooled Ge diode detector. A total of 256 scans was collected for each spectrum. Diffraction data were collected at 100(2) K on an Oxford Diffraction Gemini diffractometer fitted with graphite-monochromated Mo K $\alpha$ radiation. Following analytical absorption corrections and solution by direct methods, the structure was refined against $F^{2}$ with full-matrix least-squares using the program SHELXL97. ${ }^{39}$ The solid-state emission spectrum was measured with a Varian Carey Eclipse $\left(\lambda_{\mathrm{ex}}=420\right.$ $\mathrm{nm})$. The sample was kept inside a glass vial and the measurement was performed using an optical fiber in close contact with the solid at the end of the vial. The solution state emission spectrum was measured from an aerated $10^{-4} \mathrm{M}$ ethyl acetate solution using a Hitachi F-7000 Fluorescence Spectrometer $\left(\lambda_{\mathrm{ex}}=420 \mathrm{~nm}\right)$. Variable temperature magnetic susceptibility measurements were carried out in the temperature range 5-350 $\mathrm{K}$ with an applied magnetic field of $7.96 \mathrm{kA} / \mathrm{m}$ using a SQUID based magnetometry system (Quantum Design MPMS-7).

General Procedure for the Synthesis of the Lanthanoid Clusters: 2 eq. of abzmH were added to methanol $(30 \mathrm{ml})$ and heated, while stirring, until all the solid was completely dissolved. 1 eq. of the corresponding hexahydrated $\mathrm{LnCl}_{3}(\mathrm{Ln}=\mathrm{Eu}, \mathrm{Tb}, \mathrm{Ho})$ was then added. The solution was stirred for $15 \mathrm{~min}$ and then an excess of triethylamine, usually higher than 10 eq., was added. The resulting solution was refluxed for $16 \mathrm{~h}$. After this time, the solvent and excess triethylamine were removed under reduced pressure using a rotary evaporator. The leftover solid was triturated with toluene and then filtered to remove triethylammonium chloride. The toluene solution was concentrated and the corresponding clusters were obtained 
by precipitation upon addition of hexane. Single crystals suitable for X-ray diffraction were grown by vapour diffusion of hexane into a solution of the cluster in toluene. Yields are quoted with respect to the initial amount of $\mathrm{LnCl}_{3}\left(\mathrm{H}_{2} \mathrm{O}\right)_{6}$.

Analytical Data for $\left[\mathbf{E u}_{5}(\mathbf{O H})_{5}(\mathbf{a b z m})_{10}\right]:$ Yield $186 \mathrm{mg}(54 \%)$; IR (diamond ATR): $v=$ 3597 (wb), 3074 (w), 2987 (w), 2917 (w), 2864 (w), 1591 (s), 1526 (w), 1480 (s), 1426 (s), 1379 (s), 1300 (m), 1249 (m), 1212 (s), 1168 (s), 1129 (s), 1106 (s), 1058 (s), 990 (m), 918 (m), $883(\mathrm{~m}), 778(\mathrm{~s}), 701(\mathrm{w}), 626 \mathrm{~cm}^{-1}$ (w); Anal. calcd. for $\mathrm{C}_{210} \mathrm{H}_{195} \mathrm{O}_{45} \mathrm{Eu}_{5}: \mathrm{C}$ 60.07, H 4.68; found: C $60.32, \mathrm{H} 4.80$.

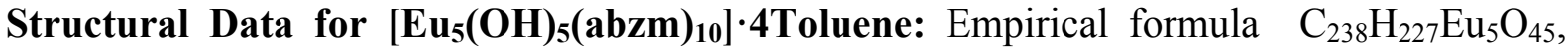
Formula weight 4567.00, Wavelength 0.71073 Å, Crystal system Monoclinic, Space group $C 2 / \mathrm{c}$, Unit cell dimensions $\mathrm{a}=35.8542(9) \AA, \mathrm{b}=17.7867(4) \AA, \mathrm{c}=32.6504(5) \AA, \beta=$ 95.338(2) ${ }^{\circ}$, Volume 20731.8(8) $\AA^{3}, Z=4$, Density (calculated) $1.463 \mathrm{Mg} / \mathrm{m}^{3}$, Absorption coefficient $1.569 \mathrm{~mm}^{-1}, \mathrm{~F}(000) 9320$, Crystal size $0.34 \times 0.17 \times 0.11 \mathrm{~mm}^{3}, \theta$ range for data collection 3.46 to $34.56^{\circ}$, Index ranges $-56<=\mathrm{h}<=56,-26<=\mathrm{k}<=28,-51<=1<=51$, Reflections collected 192070, Independent reflections $42124[\mathrm{R}(\mathrm{int})=0.0656]$, Completeness to $\theta=$ $33.75^{\circ} 99.2 \%$, Max. and min. transmission 0.909 and 0.490 , Data/restraints/parameters $42124 / 565 / 1561$, Goodness-of-fit on $\mathrm{F}^{2} 0.897$, Final $\mathrm{R}$ indices $[I>2 \sigma(I)] R_{1}=0.0440, w R_{2}=$ 0.0972, $\mathrm{R}$ indices (all data) $R_{1}=0.0962, w R_{2}=0.1079$, Largest diff. peak and hole 2.989 and 2.485 e. $\AA^{-3}$. The cluster is situated on a crystallographic 2-fold axis. The ligand which coordinates to $\mathrm{Eu}(3)$ is disordered over two sets of sites $C(7 n) / C(8 n)$ and $C(11 n) / C(12 n)$ created by an approximate $90^{\circ}$ rotation of the ligand about the 2 -fold axis. The coordinating oxygen atoms of the second component of the ligand, $\mathrm{O}(110)$ and $\mathrm{O}(120)$, are almost coincident with those of the first component, $\mathrm{O}(70)$ and $\mathrm{O}\left(80^{\prime}\right)$, of the ligand generated by the 2-fold axis. As a result of this disorder, many atoms exhibit unusually high displacement 
parameters. The ellipsoids in Figure 1 have therefore been drawn at the $20 \%$ probability level for clarity. One of ligands is disordered over two sites. Several terminal atoms of the allyl chains of four ligands were also modelled as being disordered over two sites. Site occupancies of all disordered atoms were refined to $0.589(2)$ and its complement for each of the two components after trial refinement found occupancies to be not significantly, except for $\mathrm{C}(28,29)$ and their disordered components $\mathrm{C}\left(28^{\prime}, 2^{\prime}\right)$ where the occupancies refined to $0.846(7)$ and its complement. The geometries of the disordered atoms were restrained to ideal values. All H-atoms were added at calculated positions and refined by use of a riding model with isotropic displacement parameters based on those of the parent atoms. Anisotropic displacement parameters were employed for the remainder of the non-hydrogen atoms.

Analytical Data for $\left[\mathbf{T b}_{5}(\mathbf{O H})_{5}(\mathbf{a b z m})_{10}\right]$ : Yield $213 \mathrm{mg}(67 \%)$; IR (diamond ATR): $v=$ $3624(w b), 3075(w), 3043(w), 3018$ (w), $2987(w), 1593($ s), 1545 (s), 1525 (s), 1480 (s), 1440 (s), 1426 (s), 1380 (s), 1301 (s), 1288 (m), 1249 (m), 1212 (s), 1167 (s), 1167 (s), 1128 (s), 1106 (m), 1049 (m), 1016 (m), 1007 (m), 991 (s), 921 (m), 838 (m), 778 (m), 748 (s), 701 (w), $673(\mathrm{w}), 654(\mathrm{w}), 634 \mathrm{~cm}^{-1}$ (w); Anal. calcd. for $\mathrm{C}_{210} \mathrm{H}_{195} \mathrm{O}_{45} \mathrm{~Tb}_{5}$ : C 59.58, H 4.64; found: C $60.08, \mathrm{H} 4.78$.

Structural Data for $\left[\mathbf{T b}_{5}(\mathbf{O H})_{5}(\mathbf{a b z m})_{10}\right] \cdot 4 T o l u e n e:$ Empirical formula $\mathrm{C}_{238} \mathrm{H}_{227} \mathrm{O}_{45} \mathrm{~Tb}_{5}$, Formula weight 4601.80, Wavelength $0.71073 \AA$, Crystal system Monoclinic, Space group $C 2 / c$, Unit cell dimensions $\mathrm{a}=35.7195(10) \AA, \mathrm{b}=17.7608(6) \AA, \mathrm{c}=32.6347(6) \AA, \beta=$ 95.464(2) ${ }^{\circ}$, Volume20609.6(10) $\AA^{3}, Z=4$, Density (calculated) $1.483 \mathrm{Mg} / \mathrm{m}^{3}$, Absorption coefficient $1.773 \mathrm{~mm}^{-1}, \mathrm{~F}(000) 9360$, Crystal size $0.34 \times 0.17 \times 0.11 \mathrm{~mm}^{3}, \theta$ range for data collection 3.40 to $32.17^{\circ}$, Index ranges $-51<=\mathrm{h}<=51,-25<=\mathrm{k}<=26,-47<=1<=47$, Reflections collected 118092, Independent reflections 34029 [R(int) $=0.0730]$, Completeness to $\theta=$ $31.00^{\circ} 99.3 \%$, Max. and min. transmission 0.834 and 0.690 , Data/restraints/parameters 
$34029 / 522 / 1547$, Goodness-of-fit on $\mathrm{F}^{2} 0.855$, Final $\mathrm{R}$ indices $[I>2 \sigma(I)] R_{1}=0.0514, w R_{2}=$ $0.0972, \mathrm{R}$ indices (all data) $R_{1}=0.1216, w R_{2}=0.1093$, Largest diff. peak and hole 3.261 and 2.288 e. $\AA^{-3}$. The cluster is situated on a crystallographic 2-fold axis. The ligand which coordinates to $\mathrm{Tb}(3)$ is disordered over two sets of sites $C(7 n) / C(8 n)$ and $C(11 n) / C(12 n)$ created by an approximate $90^{\circ}$ rotation of the ligand about the 2 -fold axis. The coordinating oxygen atoms of the second component of the ligand, $\mathrm{O}(110)$ and $\mathrm{O}(120)$, are almost coincident with those of the first component, $\mathrm{O}(70)$ and $\mathrm{O}\left(80^{\prime}\right)$, of the ligand generated by the 2-fold axis. As a result of this disorder, many atoms exhibit unusually high displacement parameters. One of ligands is disordered over two sites. Several terminal atoms of the allyl chains of four ligands were also modelled as being disordered over two sites. The methyl group of one solvent toluene group was also found to be disordered. Site occupancies of all disordered atoms were set at 0.5 after trial refinement. The geometries of the disordered atoms were restrained to ideal values. All H-atoms were added at calculated positions and refined by use of a riding model with isotropic displacement parameters based on those of the parent atoms. Several atoms of disordered allyl groups were refined with isotropic displacement parameters. Anisotropic displacement parameters were employed for the remainder of the non-hydrogen atoms.

Analytical Data for $\left[\mathrm{Ho}_{5}(\mathbf{O H})_{5}(\mathbf{a b z m})_{10}\right]$ : Yield $165 \mathrm{mg}(61 \%)$; IR (diamond ATR): $v=$ $3609(w b), 3071(w), 2917(w), 2864(w), 1592$ (s), 1545 (s), 1526 (s), 1482 (s), 1427 (s), 1381 (s), 1031 (m), 1249 (m), 1212 (s), 1168 (s), 1130 (s), 1105 (m), 1061 (m), 990 (m), 839 (m), 779 (m), $704(\mathrm{~m}), 623 \mathrm{~cm}^{-1}$ (w); Anal. calcd. for $\mathrm{C}_{210} \mathrm{H}_{195} \mathrm{O}_{45} \mathrm{Ho}_{5}$ : C 59.16, H 4.61; found: C 58.89, H 4.66.

Structural Data for $\left[\mathrm{Ho}_{5}(\mathrm{OH})_{5}(\mathbf{a b z m})_{10}\right] \cdot 4$ Toluene: Empirical formula $\mathrm{C}_{238} \mathrm{H}_{227} \mathrm{Ho}_{5} \mathrm{O}_{45}$, Formula weight 4631.85, Wavelength $0.71073 \AA$, Crystal system Monoclinic, Space group 
$C 2 / c$, Unit cell dimensions $\mathrm{a}=35.6653(3) \AA, \mathrm{b}=17.7996(2) \AA, \mathrm{c}=32.4926(3) \AA, \beta=$ 95.5600(10) ${ }^{\circ}$, Volume 20530.2(3) $\AA^{3}, Z=4$, Density (calculated) $1.499 \mathrm{Mg} / \mathrm{m}^{3}$, Absorption coefficient $1.984 \mathrm{~mm}^{-1}, \mathrm{~F}(000) 9400$, Crystal size $0.54 \times 0.28 \times 0.17 \mathrm{~mm}^{3}, \theta$ range for data collection 3.51 to $34.57^{\circ}$, Index ranges $-53<=\mathrm{h}<=56,-27<=\mathrm{k}<=28,-39<=1<=51$, Reflections collected 133526, Independent reflections $41528[\mathrm{R}(\mathrm{int})=0.0358]$, Completeness to $\theta=$ $33.75^{\circ} 99.2 \%$, Max. and min. transmission 0.792 and 0.480 , Data/restraints/parameters $41528 / 469 / 1549$, Goodness-of-fit on $\mathrm{F}^{2} 1.050$, Final R indices $[I>2 \sigma(I)] R_{1}=0.0486, w R_{2}=$ $0.1210, \mathrm{R}$ indices (all data) $R_{1}=0.0856, w R_{2}=0.1327$, Largest diff. peak and hole 4.397 and 2.630 e. $\AA^{-3}$. The cluster is situated on a crystallographic 2-fold axis. The ligand which coordinates to $\mathrm{Ho}(3)$ is disordered over two sets of sites $C(7 n) / C(8 n)$ and $C(11 n) / C(12 n)$ created by an approximate $90^{\circ}$ rotation of the ligand about the 2 -fold axis. The coordinating oxygen atoms of the second component of the ligand, $\mathrm{O}(110)$ and $\mathrm{O}(120)$, are almost coincident with those of the first component, $\mathrm{O}(70)$ and $\mathrm{O}\left(80^{\prime}\right)$, of the ligand generated by the 2-fold axis. As a result of this disorder, many atoms exhibit unusually high displacement parameters. One of ligands is disordered over two sites. Several terminal atoms of the allyl chains of four ligands were also modelled as being disordered over two sites. The methyl group of one solvent toluene group was also found to be disordered. Site occupancies of all disordered atoms were set at 0.5 after trial refinement. The geometries of the disordered atoms were restrained to ideal values. All H-atoms were added at calculated positions and refined by use of a riding model with isotropic displacement parameters based on those of the parent atoms. Several atoms of disordered allyl groups were refined with isotropic displacement parameters. Anisotropic displacement parameters were employed for the remainder of the non-hydrogen atoms.

General procedure for the preparation of the reinforced PMMA: In a glass vial (internal diamater $10 \mathrm{~mm}$, height $25 \mathrm{~mm})$ were added $\mathrm{AIBN},\left[\mathrm{Ln}_{5}(\mathrm{OH})_{5}(\mathbf{a b z m})_{10}\right]$, and methyl 
methacrylate $(\approx 1.0 \mathrm{ml})$ according to the concentrations listed in Table 1 . The vial was capped and heated to $90{ }^{\circ} \mathrm{C}$ for $3 \mathrm{~min}$, then quickly cooled down by immersing sequentially in a water bath at room temperature and the in an ice bath. The vial was then reheated to $45^{\circ} \mathrm{C}$ for 16 hours, $55{ }^{\circ} \mathrm{C}$ for 24 hours, $75{ }^{\circ} \mathrm{C}$ for 24 hours, and lastly $120^{\circ} \mathrm{C}$ for 3 hours. The solid polymeric material was then removed from the vial, soaked in toluene $(3 \times 20 \mathrm{~mL})$ and left under reduced pressure to remove any unreacted methyl methacrylate. For the swelling experiments, a disk of about 8-10 mm thickness was cut off and immersed for 48 hours into dichloromethane. The emission spectrum of $\mathrm{PMMA}^{\mathrm{Eu}}$ was measured at room temperature with an Hitachi F-7000 Fluorescence Spectrometer $\left(\lambda_{\mathrm{ex}}=420 \mathrm{~nm}\right)$.

† Electronic Supplementary Information (ESI) available: selected bond lengths and angles for the cluster and Raman spectrum of the abzmH ligand. CCDC 779681, 779682, and 779683 (for $\left.\left[\mathrm{Eu}_{5}(\mathrm{OH})_{5}(\mathbf{a b z m})_{10}\right], \quad\left[\mathrm{Tb}_{5}(\mathrm{OH})_{5}(\mathbf{a b z m})_{10}\right]\right)$, and $\left[\mathrm{Ho}_{5}(\mathrm{OH})_{5}(\mathbf{a b z m})_{10}\right]$ respectively) contain the supplementary crystallographic data for this manuscript. These data can be obtained free of charge from The Cambridge Crystallographic Data Centre via www.ccdc.cam.ac.uk/data_request/cif.

\section{Acknowledgements}

This work was supported by the Australian Research Council. M.M. wish to thank the ARC for the APD Fellowship DP0985481. D.H.B. wish to thank Curtin University of Technology for a Curtin Research and Teaching Fellowship. Prof. Bill van Bronswijk and Mr Peter Chapman (Curtin University of Technology) are kindly acknowledged for useful discussion.

\section{References:}

1. U. Schubert, Macromol. Symp., 2008, 267, 1.

2. J. H. Burroughes, D. D. C. Bradley, A. R. Brown, R. N. Marks, K. Mackay, R. H. Friend, P. L. Burns and A. B. Holmes, Nature, 1990, 347, 539.

3. J. Thomas, R. A. Norwood and N. Peyghambarian, J. Mater. Chem., 2009, 19, 7476.

4. M. Cavallini, J. Gomez-Segura, D. Ruiz-Molina, M. Massi, C. Albonetti, C. Rovira, J. Veciana and F. Biscarini, Angew. Chem. Int. Ed., 2005, 44, 888.

5. C. Guan, C. L. Lu, Y. R. Cheng, S. Y. Song and B. Yang, J. Mater. Chem., 2009, 19, 617. 
6. S. H. Li, J. Qin, A. Fornara, M. Toprak, M. Muhammed and D. K. Kim, Nanotechnology, 2009, 20, 1.

7. H. Althues, R. Palkovits, A. Rumplecker, P. Simon, W. Sigle, M. Bredol, U. Kynast and S. Kaskel, Chem. Mater., 2006, 18, 1068.

8. J. C. Boyer, N. J. J. Johnson and F. C. J. M. van Veggel, Chem. Mater., 2009, 21, 2010.

9. P. K. Khanna and N. Singh, J. Lumin. , 2007, 127, 474.

10. H. Althues, P. Simon and S. Kaskel, J. Mater. Chem., 2007, 17, 758.

11. U. Schubert, Chem. Mater., 2001, 13, 3487.

12. P. K. Das, I. Ruzmaikina and L. A. Belfiore, J. Polym. Sci., Part B: Polym. Phys., 2000, 38, 1931.

13. M. Massi, C. Albonetti, M. Facchini, M. Cavallini and F. Biscarini, Adv. Mater., 2006, 18, 2739.

14. Y. Molard, F. Dorson, K. A. Brylev, M. A. Shestopalov, Y. Le Gal, S. Cordier, Y. V. Mironov, N. Kitamura and C. Perrin, Chem. Eur. J., 2010, 16, 5613.

15. F. Palacio, P. Oliete, U. Schubert, I. Mijatovic, N. Husing and H. Peterlik, J. Mater. Chem., 2004, 14, 1873.

16. U. Schubert, J. Sol-Gel Sci. Technol. , 2004, 31, 18.

17. F. R. Kogler, T. Koch, H. Peterlik, S. Seidler and U. Schubert, J. Polym. Sci., Part B: Polym. Phys., 2007, 45, 2215.

18. Z. P. Zheng and R. Y. Wang, Comments Inorg. Chem., 2000, 22, 1.

19. R. Y. Wang, M. D. Carducci and Z. P. Zheng, Inorg. Chem., 2000, 39, 1836.

20. R. Y. Wang, H. Liu, M. D. Carducci, T. Z. Jin, C. Zheng and Z. P. Zheng, Inorg. Chem., 2001, 40, 2743.

21. X. J. Kong, L. S. Long, L. S. Zheng, R. Y. Wang and Z. P. Zheng, Inorg. Chem., 2009, 48, 3268.

22. S. Datta, V. Baskar, H. Li and P. W. Roesky, Eur. J. Inorg. Chem., 2007, 4216.

23. S. Petit, F. Baril-Robert, G. Pilet, C. Reber and D. Luneau, Dalton Trans., 2009, 6809.

24. X. Y. Chen, X. P. Yang and B. J. Holliday, Inorg. Chem., 2010, 49, 2583.

25. P. C. Andrews, T. Beck, B. H. Fraser, P. C. Junk, M. Massi, B. Moubaraki, K. S. Murray and M. Silberstein, Polyhedron, 2009, 28, 2123.

26. P. C. Andrews, G. B. Deacon, R. Frank, B. H. Fraser, P. C. Junk, J. G. MacLellan, M. Massi, B. Moubaraki, K. S. Murray and M. Silberstein, Eur. J. Inorg. Chem., 2009, 744.

27. P. C. Andrews, W. J. Gee, P. C. Junk and J. G. MacLellan, Inorg. Chem., 2010, 49, 5016.

28. M. R. Burgstein, M. T. Gamer and P. W. Roesky, J. Am. Chem. Soc., 2004, 126, 5213.

29. M. T. Gamer, Y. Lan, P. W. Roesky, A. K. Powell and R. Clerac, Inorg. Chem., 2008, 47, 6581 .

30. G. F. de Sa, O. L. Malta, C. D. Donega, A. M. Simas, R. L. Longo, P. A. Santa-Cruz and E. F. da Silva, Coord. Chem. Rev., 2000, 196, 165.

31. J. C. G. Bunzli, Acc. Chem. Res. , 2006, 39, 53.

32. A. de Bettencourt-Dias, Dalton Trans., 2007, 2229.

33. P. Xie, Z. Shen, Y. Liu, B. Kong, C. Liu, R. Zhang, Z. Fan, R. Bai, T.-S. Chung and C. He, Liq. Cryst. , 2001, 28, 477.

34. N. Mahe, O. Guillou, C. Daiguebonne, Y. Gerault, A. Caneschi, C. Sangregorio, J. Y. Chane-Ching, P. E. Car and T. Roisnel, Inorg. Chem., 2005, 44, 7743.

35. A. Dossing, Eur. J. Inorg. Chem., 2005, 1425.

36. M. Andruh, E. Bakalbassis, O. Kahn, J. C. Trombe and P. Porcher, Inorg. Chem., 1993, 32, 1616. 
37. Y. Gao, F. R. Kogler and U. Schubert, J. Polym. Sci., Part A: Polym. Chem., 2005, 43, 6586 .

38. R. Reisfeld, R. A. Velapoldi, L. Boehm and M. Ish-Shalom, J. Phys. Chem., 1971, 75, 3980.

39. G. M. Sheldrick, Acta Cryst., 2008, A64, 112. 

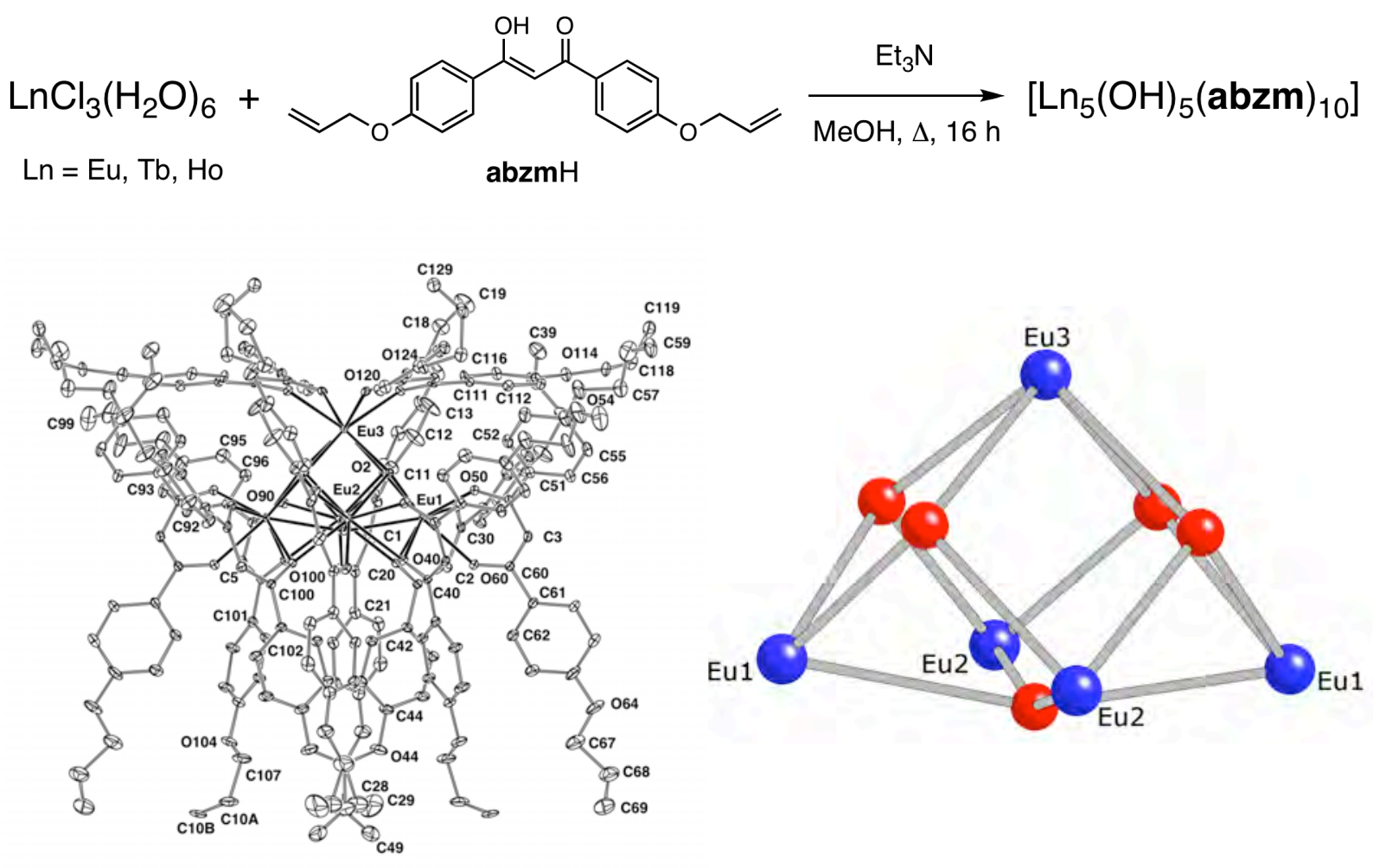

Figure 1. Synthesis of the pentanuclear allyloxy-functionalized clusters (top). X-ray crystal structure of $\left[\mathrm{Eu}_{5}(\mathrm{OH})_{5}(\mathbf{a b z m})_{10}\right]$ with thermal ellipsoids drawn at the $20 \%$ probability level, hydrogen atoms and lattice solvent molecules have been omitted for clarity (bottom left). View of the pentanuclear Eu cluster core including the $\mu_{3}$-coordinated $\mathrm{OH}$ ligands on each of the four sides and the $\mu_{4} \mathrm{OH}$ ligand at the base of the structure (bottom right). 


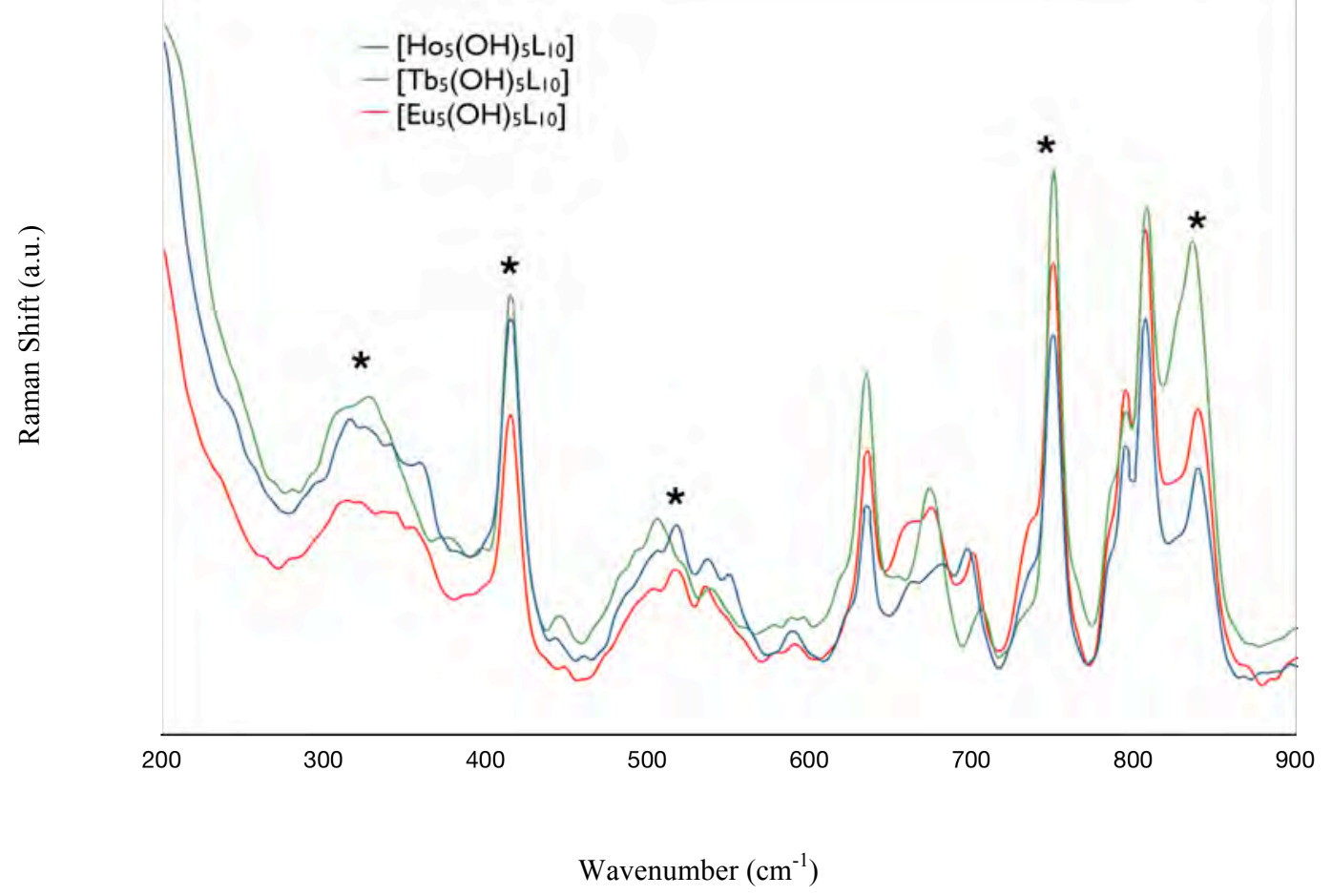

Figure 2. Raman spectra for the pentanuclear allyl functionalised clusters of Eu (red line), $\mathrm{Tb}$ (green line), and Ho (blue line). The * marks highlight characteristic Ln-O Raman shifts for pentanuclear square-based pyramidal clusters. 


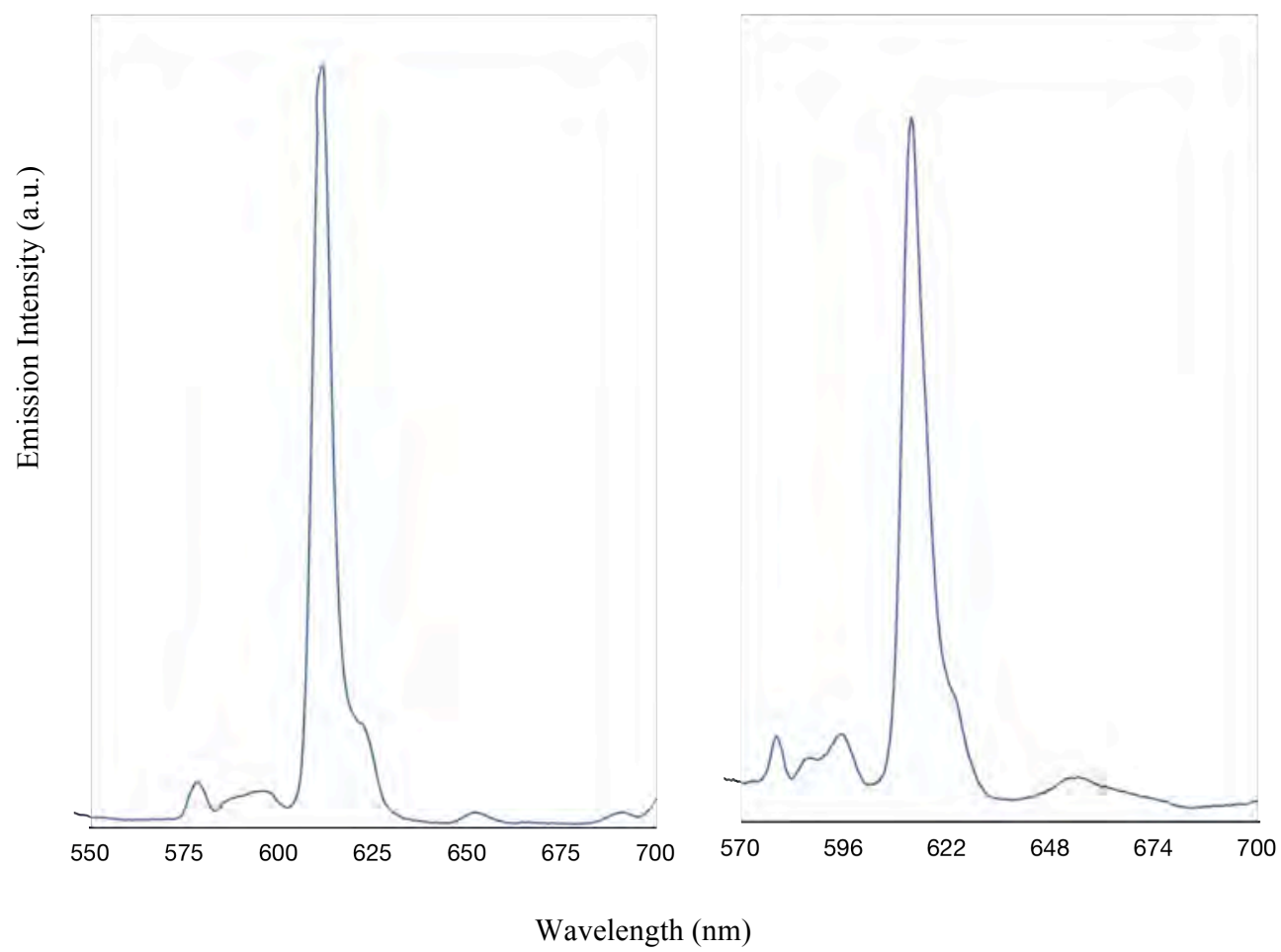

Figure 3. Visible emission profile for $\left[\mathrm{Eu}_{5}(\mathrm{OH})_{5}(\mathrm{abzm})_{10}\right]$ in the solid state (left) and in solution (right). 


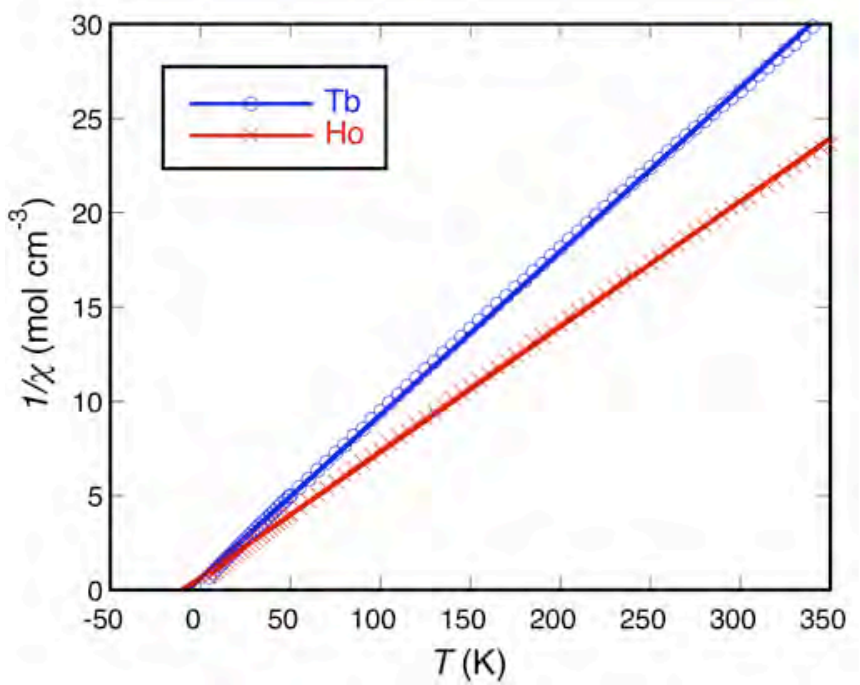

Figure 4. The temperature dependence of the inverse magnetic susceptibility $1 / \chi$ for $\left[\mathrm{Tb}_{5}(\mathrm{OH})_{5}(\mathbf{a b z m})_{10}\right]$ (circles) and $\left[\mathrm{Ho}_{5}(\mathrm{OH})_{5}(\mathbf{a b z m})_{10}\right]$ (crosses). 


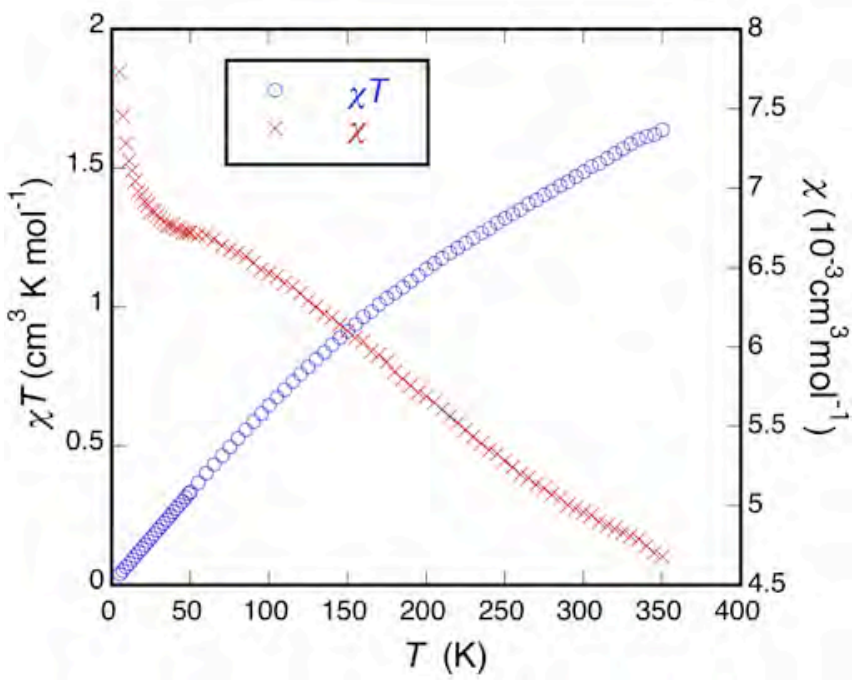

Figure 5. The temperature dependence of the magnetic susceptibility $\chi$ (crosses) and $\chi \mathrm{T}$ (circles) for $\left[\mathrm{Eu}_{5}(\mathrm{OH})_{5}(\mathbf{a b z m})_{10}\right]$. 

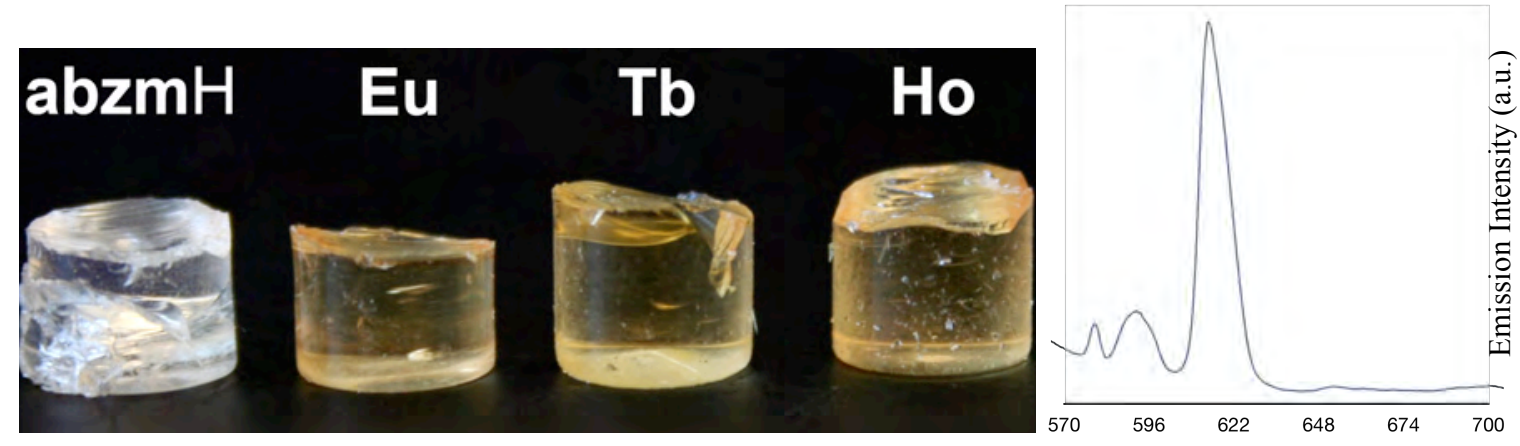

Wavelength (nm)

Figure 6. Picture of the $\mathrm{PMMA}^{\mathrm{LH}}$ and the three $\mathrm{PMMA}^{\mathrm{Ln}}$ taken after removal of solvent from the respective $\mathrm{CH}_{2} \mathrm{Cl}_{2}$ swollen sections (left). Emission profile of $\mathrm{PMMA}^{\mathrm{Eu}}$ (right) $\left(\lambda_{\mathrm{ex}}=420\right.$ $\mathrm{nm})$. 
Table 1. Summary of polymerization conditions and swelling measurements.

\begin{tabular}{cccccc}
\hline Material & Crosslinker & \multicolumn{2}{c}{ Crosslinker \% [a] } & AlBN \% [a] & Swelling \% [c] \\
\hline PMMA $^{\text {LH }}$ & abzmH & \multicolumn{2}{c}{0.6} & 0.4 & $123 \pm 5$ \\
PMMA $^{\mathrm{Eu}}$ & {$\left[\mathrm{Eu}_{5}(\mathrm{OH})_{5}(\text { abzm })_{10}\right]$} & 0.04 & $(0.4[\mathrm{~b}])$ & 0.3 & $110 \pm 5$ \\
PMMA $^{\text {Tb }}$ & {$\left[\mathrm{Tb}_{5}(\mathrm{OH})_{5}(\mathbf{a b z m})_{10}\right]$} & 0.03 & $(0.3[\mathrm{~b}])$ & 0.3 & $110 \pm 5$ \\
PMMA $^{\mathrm{Ho}}$ & {$\left[\mathrm{Ho}_{5}(\mathrm{OH})_{5}(\mathbf{a b z m})_{10}\right]$} & 0.04 & $(0.4[\mathrm{~b}])$ & 0.1 & $110 \pm 5$
\end{tabular}

[a] Molar percentage. [b] The molar percentage of actual abzm. [c] Swelling data were obtained by measuring the diameter of a $10 \mathrm{~mm}$ disk of material after immersion in $\mathrm{CH}_{2} \mathrm{Cl}_{2}$ for 48 hours. 


\section{Graphical Abstract}

The radical polymerisation of methyl methacrylate and allyl functionalized lanthanoid clusters yields novel hybrid inorganic-organic materials. The matrix is completely transparent while the cluster favors chain crosslinking, thus producing reinforced polymers, and confers optical and magnetic properties associated with the presence of the f-block elements.

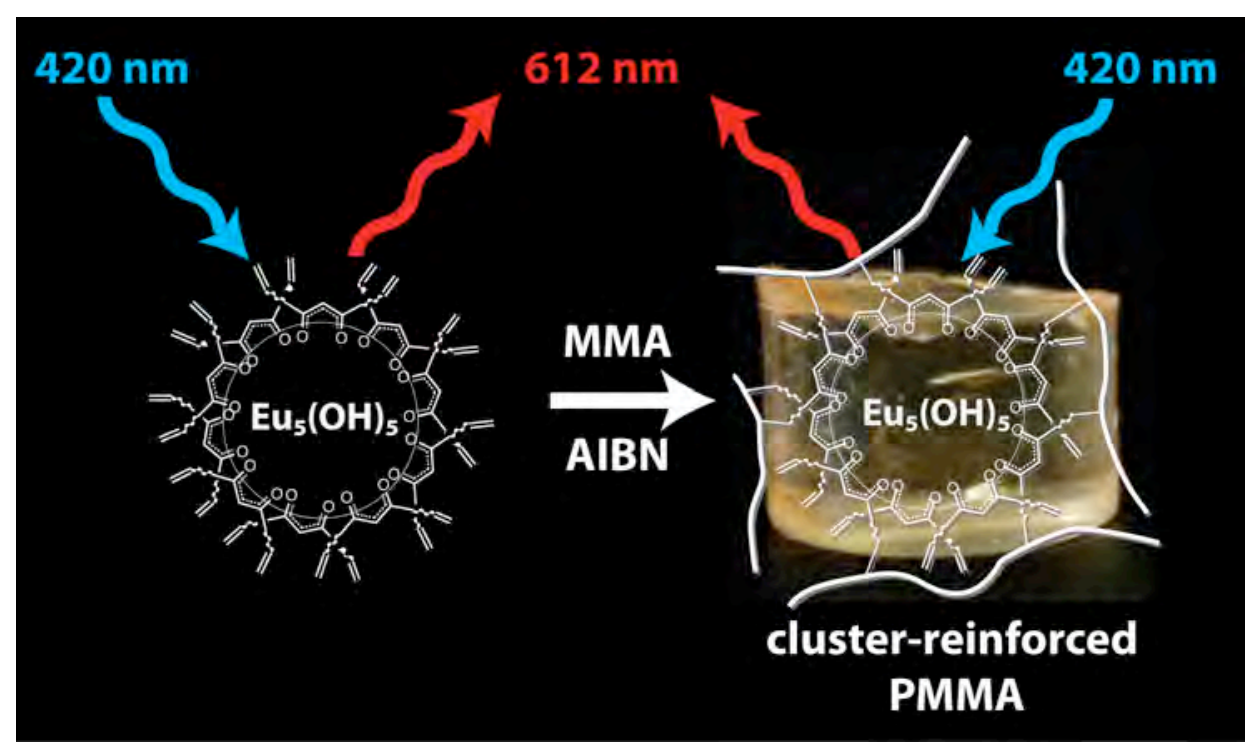




\section{Electronic Supplementary Information}

Selected bond lengths and angles

Selected bond lengths $[\AA]$ and angles $\left[{ }^{\circ}\right]$ for $\left[\mathrm{Eu}_{5}(\mathrm{OH})_{5}(\mathbf{a b z m})_{10}\right] \cdot 4$ Toluene.

\begin{tabular}{|c|c|}
\hline $\mathrm{Eu}(1)-\mathrm{O}(50)$ & $2.3190(18)$ \\
\hline $\mathrm{Eu}(1)-\mathrm{O}(60)$ & $2.3265(18)$ \\
\hline $\mathrm{Eu}(1)-\mathrm{O}(3)$ & $2.3599(17)$ \\
\hline $\mathrm{Eu}(1)-\mathrm{O}(40)$ & $2.3721(18)$ \\
\hline $\mathrm{Eu}(1)-\mathrm{O}(2)$ & $2.3843(17)$ \\
\hline $\mathrm{Eu}(1)-\mathrm{O}(30)$ & $2.4050(19)$ \\
\hline $\mathrm{Eu}(1)-\mathrm{O}(100)^{1}$ & $2.4832(18)$ \\
\hline $\mathrm{Eu}(1)-\mathrm{O}(1)$ & $2.6487(4)$ \\
\hline $\mathrm{Eu}(2)-\mathrm{O}(10)$ & $2.3078(18)$ \\
\hline $\mathrm{Eu}(2)-\mathrm{O}(20)$ & $2.3294(19)$ \\
\hline $\mathrm{Eu}(2)-\mathrm{O}(2)$ & $2.3509(17)$ \\
\hline $\mathrm{Eu}(2)-\mathrm{O}(90)$ & $2.3555(19)$ \\
\hline $\mathrm{Eu}(2)-\mathrm{O}(100)$ & $2.3994(17)$ \\
\hline $\mathrm{Eu}(2)-\mathrm{O}(3)^{1}$ & $2.3997(18)$ \\
\hline $\mathrm{Eu}(2)-\mathrm{O}(40)$ & $2.4928(18)$ \\
\hline $\mathrm{Eu}(2)-\mathrm{O}(1)$ & $2.5288(4)$ \\
\hline $\mathrm{Eu}(3)-\mathrm{O}(70)$ & $2.331(8)$ \\
\hline $\mathrm{Eu}(3)-\mathrm{O}(80)$ & $2.335(8)$ \\
\hline $\mathrm{Eu}(3)-\mathrm{O}(110)$ & $2.355(6)$ \\
\hline $\mathrm{Eu}(3)-\mathrm{O}(120)$ & $2.393(5)$ \\
\hline $\mathrm{Eu}(3)-\mathrm{O}(3)$ & $2.4433(17)$ \\
\hline $\mathrm{Eu}(3)-\mathrm{O}(2)$ & $2.4674(17)$ \\
\hline $\mathrm{O}(50)-\mathrm{Eu}(1)-\mathrm{O}(60)$ & $72.75(7)$ \\
\hline $\mathrm{O}(50)-\mathrm{Eu}(1)-\mathrm{O}(3)$ & $76.92(6)$ \\
\hline $\mathrm{O}(60)-\mathrm{Eu}(1)-\mathrm{O}(3)$ & $140.23(7)$ \\
\hline $\mathrm{O}(50)-\mathrm{Eu}(1)-\mathrm{O}(40)$ & $152.33(6)$ \\
\hline $\mathrm{O}(60)-\mathrm{Eu}(1)-\mathrm{O}(40)$ & $81.55(6)$ \\
\hline
\end{tabular}




\begin{tabular}{|c|c|}
\hline $\mathrm{O}(3)-\mathrm{Eu}(1)-\mathrm{O}(40)$ & $130.69(6)$ \\
\hline $\mathrm{O}(50)-\mathrm{Eu}(1)-\mathrm{O}(2)$ & $116.58(6)$ \\
\hline $\mathrm{O}(60)-\mathrm{Eu}(1)-\mathrm{O}(2)$ & $146.18(7)$ \\
\hline $\mathrm{O}(3)-\mathrm{Eu}(1)-\mathrm{O}(2)$ & $71.46(6)$ \\
\hline $\mathrm{O}(40)-\mathrm{Eu}(1)-\mathrm{O}(2)$ & $79.95(6)$ \\
\hline $\mathrm{O}(50)-\mathrm{Eu}(1)-\mathrm{O}(30)$ & $91.51(6)$ \\
\hline $\mathrm{O}(60)-\mathrm{Eu}(1)-\mathrm{O}(30)$ & $76.12(7)$ \\
\hline $\mathrm{O}(3)-\mathrm{Eu}(1)-\mathrm{O}(30)$ & $130.25(6)$ \\
\hline $\mathrm{O}(40)-\mathrm{Eu}(1)-\mathrm{O}(30)$ & $72.15(6)$ \\
\hline $\mathrm{O}(2)-\mathrm{Eu}(1)-\mathrm{O}(30)$ & $71.36(6)$ \\
\hline $\mathrm{O}(50)-\mathrm{Eu}(1)-\mathrm{O}(100)^{1}$ & $90.62(6)$ \\
\hline $\mathrm{O}(60)-\mathrm{Eu}(1)-\mathrm{O}(100)^{1}$ & $78.35(6)$ \\
\hline $\mathrm{O}(3)-\mathrm{Eu}(1)-\mathrm{O}(100)^{1}$ & $76.85(6)$ \\
\hline $\mathrm{O}(40)-\mathrm{Eu}(1)-\mathrm{O}(100)^{1}$ & $94.13(6)$ \\
\hline $\mathrm{O}(2)-\mathrm{Eu}(1)-\mathrm{O}(100)^{1}$ & $130.95(6)$ \\
\hline $\mathrm{O}(30)-\mathrm{Eu}(1)-\mathrm{O}(100)^{1}$ & $152.47(6)$ \\
\hline $\mathrm{O}(50)-\mathrm{Eu}(1)-\mathrm{O}(1)$ & $140.46(5)$ \\
\hline $\mathrm{O}(60)-\mathrm{Eu}(1)-\mathrm{O}(1)$ & $128.17(7)$ \\
\hline $\mathrm{O}(3)-\mathrm{Eu}(1)-\mathrm{O}(1)$ & $66.96(6)$ \\
\hline $\mathrm{O}(40)-\mathrm{Eu}(1)-\mathrm{O}(1)$ & $65.10(5)$ \\
\hline $\mathrm{O}(2)-\mathrm{Eu}(1)-\mathrm{O}(1)$ & $66.97(6)$ \\
\hline $\mathrm{O}(30)-\mathrm{Eu}(1)-\mathrm{O}(1)$ & $123.88(5)$ \\
\hline $\mathrm{O}(100)^{1}-\mathrm{Eu}(1)-\mathrm{O}(1)$ & $66.53(5)$ \\
\hline $\mathrm{O}(10)-\mathrm{Eu}(2)-\mathrm{O}(20)$ & $73.39(7)$ \\
\hline $\mathrm{O}(10)-\mathrm{Eu}(2)-\mathrm{O}(2)$ & $76.07(6)$ \\
\hline $\mathrm{O}(20)-\mathrm{Eu}(2)-\mathrm{O}(2)$ & $137.86(6)$ \\
\hline $\mathrm{O}(10)-\mathrm{Eu}(2)-\mathrm{O}(90)$ & $82.51(7)$ \\
\hline $\mathrm{O}(20)-\mathrm{Eu}(2)-\mathrm{O}(90)$ & $78.23(7)$ \\
\hline $\mathrm{O}(2)-\mathrm{Eu}(2)-\mathrm{O}(90)$ & $125.50(6)$ \\
\hline $\mathrm{O}(10)-\mathrm{Eu}(2)-\mathrm{O}(100)$ & $147.11(6)$ \\
\hline $\mathrm{O}(20)-\mathrm{Eu}(2)-\mathrm{O}(100)$ & $80.43(6)$ \\
\hline $\mathrm{O}(2)-\mathrm{Eu}(2)-\mathrm{O}(100)$ & $136.24(6)$ \\
\hline $\mathrm{O}(90)-\mathrm{Eu}(2)-\mathrm{O}(100)$ & $72.82(6)$ \\
\hline $\mathrm{O}(10)-\mathrm{Eu}(2)-\mathrm{O}(3)^{1}$ & $115.22(7)$ \\
\hline
\end{tabular}




\begin{tabular}{|c|c|}
\hline $\mathrm{O}(20)-\mathrm{Eu}(2)-\mathrm{O}(3)^{1}$ & $147.09(6)$ \\
\hline $\mathrm{O}(2)-\mathrm{Eu}(2)-\mathrm{O}(3)^{1}$ & $73.20(6)$ \\
\hline $\mathrm{O}(90)-\mathrm{Eu}(2)-\mathrm{O}(3)^{1}$ & $71.98(6)$ \\
\hline $\mathrm{O}(100)-\mathrm{Eu}(2)-\mathrm{O}(3)^{1}$ & $77.74(6)$ \\
\hline $\mathrm{O}(10)-\mathrm{Eu}(2)-\mathrm{O}(40)$ & $93.97(7)$ \\
\hline $\mathrm{O}(20)-\mathrm{Eu}(2)-\mathrm{O}(40)$ & $75.74(6)$ \\
\hline $\mathrm{O}(2)-\mathrm{Eu}(2)-\mathrm{O}(40)$ & $78.17(6)$ \\
\hline $\mathrm{O}(90)-\mathrm{Eu}(2)-\mathrm{O}(40)$ & $153.63(6)$ \\
\hline $\mathrm{O}(100)-\mathrm{Eu}(2)-\mathrm{O}(40)$ & $98.58(6)$ \\
\hline $\mathrm{O}(3)^{1}-\mathrm{Eu}(2)-\mathrm{O}(40)$ & $131.66(6)$ \\
\hline $\mathrm{O}(10)-\mathrm{Eu}(2)-\mathrm{O}(1)$ & $142.57(5)$ \\
\hline $\mathrm{O}(20)-\mathrm{Eu}(2)-\mathrm{O}(1)$ & $125.37(7)$ \\
\hline $\mathrm{O}(2)-\mathrm{Eu}(2)-\mathrm{O}(1)$ & $69.51(6)$ \\
\hline $\mathrm{O}(90)-\mathrm{Eu}(2)-\mathrm{O}(1)$ & $129.80(5)$ \\
\hline $\mathrm{O}(100)-\mathrm{Eu}(2)-\mathrm{O}(1)$ & $69.70(5)$ \\
\hline $\mathrm{O}(3)^{1}-\mathrm{Eu}(2)-\mathrm{O}(1)$ & $68.43(6)$ \\
\hline $\mathrm{O}(40)-\mathrm{Eu}(2)-\mathrm{O}(1)$ & $65.35(5)$ \\
\hline $\mathrm{O}(70)-\mathrm{Eu}(3)-\mathrm{O}(70)^{1}$ & $118.8(5)$ \\
\hline $\mathrm{O}(70)-\mathrm{Eu}(3)-\mathrm{O}(80)$ & $73.1(3)$ \\
\hline $\mathrm{O}(70)-\mathrm{Eu}(3)-\mathrm{O}(80)^{1}$ & $77.0(3)$ \\
\hline $\mathrm{O}(80)-\mathrm{Eu}(3)-\mathrm{O}(80)^{1}$ & 119.2(3) \\
\hline $\mathrm{O}(70)^{1}-\mathrm{Eu}(3)-\mathrm{O}(110)$ & $116.59(12)$ \\
\hline $\mathrm{O}(80)-\mathrm{Eu}(3)-\mathrm{O}(110)$ & $70.2(2)$ \\
\hline $\mathrm{O}(80)^{1}-\mathrm{Eu}(3)-\mathrm{O}(110)$ & $77.9(2)$ \\
\hline $\mathrm{O}(110)-\mathrm{Eu}(3)-\mathrm{O}(110)^{1}$ & $114.5(3)$ \\
\hline $\mathrm{O}(70)-\mathrm{Eu}(3)-\mathrm{O}(120)^{1}$ & $77.5(3)$ \\
\hline $\mathrm{O}(110)-\mathrm{Eu}(3)-\mathrm{O}(120)^{1}$ & $74.5(2)$ \\
\hline $\mathrm{O}(70)-\mathrm{Eu}(3)-\mathrm{O}(120)$ & $71.4(3)$ \\
\hline $\mathrm{O}(80)-\mathrm{Eu}(3)-\mathrm{O}(120)$ & $117.63(12)$ \\
\hline $\mathrm{O}(110)-\mathrm{Eu}(3)-\mathrm{O}(120)$ & $72.5(2)$ \\
\hline $\mathrm{O}(120)^{1}-\mathrm{Eu}(3)-\mathrm{O}(120)$ & $116.7(3)$ \\
\hline $\mathrm{O}(70)-\mathrm{Eu}(3)-\mathrm{O}(3)^{1}$ & $133.1(2)$ \\
\hline $\mathrm{O}(80)-\mathrm{Eu}(3)-\mathrm{O}(3)^{1}$ & $74.76(19)$ \\
\hline $\mathrm{O}(110)-\mathrm{Eu}(3)-\mathrm{O}(3)^{1}$ & $131.88(18)$ \\
\hline
\end{tabular}




$\begin{array}{lc}\mathrm{O}(120)-\mathrm{Eu}(3)-\mathrm{O}(3)^{1} & 155.27(13) \\ \mathrm{O}(70)-\mathrm{Eu}(3)-\mathrm{O}(3) & 85.4(2) \\ \mathrm{O}(70)^{1}-\mathrm{Eu}(3)-\mathrm{O}(3) & 133.1(2) \\ \mathrm{O}(80)-\mathrm{Eu}(3)-\mathrm{O}(3) & 149.57(17) \\ \mathrm{O}(80)^{1}-\mathrm{Eu}(3)-\mathrm{O}(3) & 74.76(19) \\ \mathrm{O}(110)-\mathrm{Eu}(3)-\mathrm{O}(3) & 88.47(17) \\ \mathrm{O}(120)-\mathrm{Eu}(3)-\mathrm{O}(3) & 73.34(14) \\ \mathrm{O}(3)^{1}-\mathrm{Eu}(3)-\mathrm{O}(3) & 107.38(8) \\ \mathrm{O}(70)-\mathrm{Eu}(3)-\mathrm{O}(2)^{1} & 152.7(2) \\ \mathrm{O}(80)-\mathrm{Eu}(3)-\mathrm{O}(2)^{1} & 134.01(19) \\ \mathrm{O}(110)-\mathrm{Eu}(3)-\mathrm{O}(2)^{1} & 155.50(17) \\ \mathrm{O}(120)-\mathrm{Eu}(3)-\mathrm{O}(2)^{1} & 89.13(13) \\ \mathrm{O}(3)-\mathrm{Eu}(3)-\mathrm{O}(2)^{1} & 70.45(6) \\ \mathrm{O}(70)-\mathrm{Eu}(3)-\mathrm{O}(2) & 73.2(2) \\ \mathrm{O}(80)-\mathrm{Eu}(3)-\mathrm{O}(2) & 84.36(17) \\ \mathrm{O}(110)-\mathrm{Eu}(3)-\mathrm{O}(2) & 74.21(18) \\ \mathrm{O}(120)-\mathrm{Eu}(3)-\mathrm{O}(2) & 129.32(13) \\ \mathrm{O}(3)-\mathrm{Eu}(3)-\mathrm{O}(2) & 68.69(6) \\ \mathrm{Eu}(2)-\mathrm{O}(1)-\mathrm{Eu}(2)^{1} & 161.80(11) \\ \mathrm{Eu}(2)-\mathrm{O}(1)-\mathrm{Eu}(1)^{1} & 88.855(18) \\ \mathrm{Eu}(2)-\mathrm{O}(1)-\mathrm{Eu}(1) & 88.133(18) \\ \mathrm{Eu}(1)^{1}-\mathrm{O}(1)-\mathrm{Eu}(1) & 160.87(10) \\ \mathrm{Eu}(2)-\mathrm{O}(2)-\mathrm{Eu}(1) & 99.04(7) \\ \mathrm{Eu}(2)-\mathrm{O}(2)-\mathrm{Eu}(3) & 108.18(6) \\ \mathrm{Eu}(1)-\mathrm{O}(2)-\mathrm{Eu}(3) & 108.89(7) \\ \mathrm{Eu}(1)-\mathrm{O}(3)-\mathrm{Eu}(2)^{1} & 99.22(7) \\ \mathrm{Eu}(1)-\mathrm{O}(3)-\mathrm{Eu}(3) & 110.52(7) \\ \mathrm{Eu}(2)^{1}-\mathrm{O}(3)-\mathrm{Eu}(3) & 107.39(6) \\ & \end{array}$

Symmetry transformations used to generate equivalent atoms: ${ }^{1}-\mathrm{x}, \mathrm{y},-\mathrm{z}+1 / 2$

Selected bond lengths $[\AA]$ and angles $\left[^{\circ}\right]$ for $\left[\mathrm{Tb}_{5}(\mathrm{OH})_{5}(\mathbf{a b z m})_{10}\right] \cdot 4$ Toluene.

\begin{tabular}{ll}
\hline $\mathrm{Tb}(1)-\mathrm{O}(50)$ & $2.296(2)$ \\
$\mathrm{Tb}(1)-\mathrm{O}(60)$ & $2.308(3)$
\end{tabular}




\begin{tabular}{|c|c|}
\hline $\mathrm{Tb}(1)-\mathrm{O}(3)$ & $2.344(2)$ \\
\hline $\mathrm{Tb}(1)-\mathrm{O}(40)$ & $2.346(2)$ \\
\hline $\mathrm{Tb}(1)-\mathrm{O}(2)$ & $2.357(2)$ \\
\hline $\mathrm{Tb}(1)-\mathrm{O}(30)$ & $2.378(3)$ \\
\hline $\mathrm{Tb}(1)-\mathrm{O}(100)^{1}$ & $2.452(2)$ \\
\hline $\mathrm{Tb}(1)-\mathrm{O}(1)$ & $2.6212(7)$ \\
\hline $\mathrm{Tb}(1) \ldots \mathrm{Tb}(2)$ & $3.5651(2)$ \\
\hline $\mathrm{Tb}(1) \ldots \mathrm{Tb}(2)^{1}$ & $3.5787(3)$ \\
\hline $\mathrm{Tb}(1) \ldots \mathrm{Tb}(3)$ & $3.9068(3)$ \\
\hline $\mathrm{Tb}(2)-\mathrm{O}(10)$ & $2.287(3)$ \\
\hline $\mathrm{Tb}(2)-\mathrm{O}(20)$ & $2.297(3)$ \\
\hline $\mathrm{Tb}(2)-\mathrm{O}(2)$ & $2.324(2)$ \\
\hline $\mathrm{Tb}(2)-\mathrm{O}(90)$ & $2.341(2)$ \\
\hline $\mathrm{Tb}(2)-\mathrm{O}(3)^{1}$ & $2.370(3)$ \\
\hline $\mathrm{Tb}(2)-\mathrm{O}(100)$ & $2.386(2)$ \\
\hline $\mathrm{Tb}(2)-\mathrm{O}(40)$ & $2.475(2)$ \\
\hline $\mathrm{Tb}(2)-\mathrm{O}(1)$ & $2.5048(7)$ \\
\hline $\mathrm{Tb}(2) \ldots \mathrm{Tb}(1)^{1}$ & $3.5787(3)$ \\
\hline $\operatorname{Tb}(2) \ldots \mathrm{Tb}(3)$ & $3.8577(3)$ \\
\hline $\mathrm{Tb}(3)-\mathrm{O}(70)$ & $2.261(7)$ \\
\hline $\mathrm{Tb}(3)-\mathrm{O}(80)$ & $2.331(7)$ \\
\hline $\mathrm{Tb}(3)-\mathrm{O}(120)$ & $2.358(8)$ \\
\hline $\mathrm{Tb}(3)-\mathrm{O}(110)$ & $2.379(7)$ \\
\hline $\mathrm{Tb}(3)-\mathrm{O}(3)$ & $2.417(2)$ \\
\hline $\mathrm{Tb}(3)-\mathrm{O}(2)$ & $2.440(2)$ \\
\hline $\mathrm{O}(50)-\mathrm{Tb}(1)-\mathrm{O}(60)$ & $73.64(9)$ \\
\hline $\mathrm{O}(50)-\mathrm{Tb}(1)-\mathrm{O}(3)$ & $76.26(8)$ \\
\hline $\mathrm{O}(60)-\mathrm{Tb}(1)-\mathrm{O}(3)$ & $140.33(9)$ \\
\hline $\mathrm{O}(50)-\mathrm{Tb}(1)-\mathrm{O}(40)$ & $152.74(9)$ \\
\hline $\mathrm{O}(60)-\mathrm{Tb}(1)-\mathrm{O}(40)$ & $81.25(9)$ \\
\hline $\mathrm{O}(3)-\mathrm{Tb}(1)-\mathrm{O}(40)$ & $130.97(8)$ \\
\hline $\mathrm{O}(50)-\mathrm{Tb}(1)-\mathrm{O}(2)$ & $115.85(9)$ \\
\hline $\mathrm{O}(60)-\mathrm{Tb}(1)-\mathrm{O}(2)$ & $146.16(9)$ \\
\hline
\end{tabular}




\begin{tabular}{|c|c|}
\hline $\mathrm{O}(3)-\mathrm{Tb}(1)-\mathrm{O}(2)$ & $71.40(8)$ \\
\hline $\mathrm{O}(40)-\mathrm{Tb}(1)-\mathrm{O}(2)$ & $80.04(9)$ \\
\hline $\mathrm{O}(50)-\mathrm{Tb}(1)-\mathrm{O}(30)$ & $90.45(9)$ \\
\hline $\mathrm{O}(60)-\mathrm{Tb}(1)-\mathrm{O}(30)$ & $76.02(9)$ \\
\hline $\mathrm{O}(3)-\mathrm{Tb}(1)-\mathrm{O}(30)$ & $129.60(9)$ \\
\hline $\mathrm{O}(40)-\mathrm{Tb}(1)-\mathrm{O}(30)$ & $73.05(9)$ \\
\hline $\mathrm{O}(2)-\mathrm{Tb}(1)-\mathrm{O}(30)$ & $71.66(8)$ \\
\hline $\mathrm{O}(50)-\mathrm{Tb}(1)-\mathrm{O}(100)^{1}$ & $90.75(9)$ \\
\hline $\mathrm{O}(60)-\mathrm{Tb}(1)-\mathrm{O}(100)^{1}$ & $77.97(9)$ \\
\hline $\mathrm{O}(3)-\mathrm{Tb}(1)-\mathrm{O}(100)^{1}$ & $77.20(9)$ \\
\hline $\mathrm{O}(40)-\mathrm{Tb}(1)-\mathrm{O}(100)^{1}$ & $94.31(9)$ \\
\hline $\mathrm{O}(2)-\mathrm{Tb}(1)-\mathrm{O}(100)^{1}$ & $131.32(8)$ \\
\hline $\mathrm{O}(30)-\mathrm{Tb}(1)-\mathrm{O}(100)^{1}$ & $152.48(9)$ \\
\hline $\mathrm{O}(50)-\mathrm{Tb}(1)-\mathrm{O}(1)$ & $140.49(7)$ \\
\hline $\mathrm{O}(60)-\mathrm{Tb}(1)-\mathrm{O}(1)$ & $127.55(10)$ \\
\hline $\mathrm{O}(3)-\mathrm{Tb}(1)-\mathrm{O}(1)$ & $67.55(8)$ \\
\hline $\mathrm{O}(40)-\mathrm{Tb}(1)-\mathrm{O}(1)$ & $64.87(8)$ \\
\hline $\mathrm{O}(2)-\mathrm{Tb}(1)-\mathrm{O}(1)$ & $67.27(8)$ \\
\hline $\mathrm{O}(30)-\mathrm{Tb}(1)-\mathrm{O}(1)$ & $124.71(6)$ \\
\hline $\mathrm{O}(100)^{1}-\mathrm{Tb}(1)-\mathrm{O}(1)$ & $66.72(7)$ \\
\hline $\mathrm{O}(10)-\mathrm{Tb}(2)-\mathrm{O}(20)$ & $74.06(10)$ \\
\hline $\mathrm{O}(10)-\mathrm{Tb}(2)-\mathrm{O}(2)$ & $75.54(9)$ \\
\hline $\mathrm{O}(20)-\mathrm{Tb}(2)-\mathrm{O}(2)$ & $137.76(8)$ \\
\hline $\mathrm{O}(10)-\mathrm{Tb}(2)-\mathrm{O}(90)$ & $81.71(9)$ \\
\hline $\mathrm{O}(20)-\mathrm{Tb}(2)-\mathrm{O}(90)$ & $78.25(9)$ \\
\hline $\mathrm{O}(2)-\mathrm{Tb}(2)-\mathrm{O}(90)$ & $125.10(9)$ \\
\hline $\mathrm{O}(10)-\mathrm{Tb}(2)-\mathrm{O}(3)^{1}$ & $114.48(10)$ \\
\hline $\mathrm{O}(20)-\mathrm{Tb}(2)-\mathrm{O}(3)^{1}$ & $147.12(8)$ \\
\hline $\mathrm{O}(2)-\mathrm{Tb}(2)-\mathrm{O}(3)^{1}$ & $73.25(8)$ \\
\hline $\mathrm{O}(90)-\mathrm{Tb}(2)-\mathrm{O}(3)^{1}$ & $72.14(8)$ \\
\hline $\mathrm{O}(10)-\mathrm{Tb}(2)-\mathrm{O}(100)$ & $147.51(9)$ \\
\hline $\mathrm{O}(20)-\mathrm{Tb}(2)-\mathrm{O}(100)$ & $80.30(9)$ \\
\hline $\mathrm{O}(2)-\mathrm{Tb}(2)-\mathrm{O}(100)$ & $136.35(8)$ \\
\hline $\mathrm{O}(90)-\mathrm{Tb}(2)-\mathrm{O}(100)$ & $73.70(9)$ \\
\hline
\end{tabular}




$$
\begin{aligned}
& \mathrm{O}(3)^{1}-\mathrm{Tb}(2)-\mathrm{O}(100) \quad 77.99(9) \\
& \mathrm{O}(10)-\mathrm{Tb}(2)-\mathrm{O}(40) \quad 94.07(9) \\
& \mathrm{O}(20)-\mathrm{Tb}(2)-\mathrm{O}(40) \quad \text { 75.61(9) } \\
& \mathrm{O}(2)-\mathrm{Tb}(2)-\mathrm{O}(40) \quad 78.05(8) \\
& \mathrm{O}(90)-\mathrm{Tb}(2)-\mathrm{O}(40) \quad \text { 153.66(9) } \\
& \mathrm{O}(3)^{1}-\mathrm{Tb}(2)-\mathrm{O}(40) \quad 131.89(8) \\
& \mathrm{O}(100)-\mathrm{Tb}(2)-\mathrm{O}(40) \quad 98.60(8) \\
& \mathrm{O}(10)-\mathrm{Tb}(2)-\mathrm{O}(1) \quad 142.29(7) \\
& \mathrm{O}(20)-\mathrm{Tb}(2)-\mathrm{O}(1) \quad 124.70(11) \\
& \mathrm{O}(2)-\mathrm{Tb}(2)-\mathrm{O}(1) \quad 69.79(9) \\
& \mathrm{O}(90)-\mathrm{Tb}(2)-\mathrm{O}(1) \quad 130.85(7) \\
& \mathrm{O}(3)^{1}-\mathrm{Tb}(2)-\mathrm{O}(1) \quad 69.18(9) \\
& \mathrm{O}(100)-\mathrm{Tb}(2)-\mathrm{O}(1) \quad 69.60(7) \\
& \mathrm{O}(40)-\mathrm{Tb}(2)-\mathrm{O}(1) \quad 64.96(7) \\
& \mathrm{O}(70)-\mathrm{Tb}(3)-\mathrm{O}(70)^{1} \quad 126.1(3) \\
& \mathrm{O}(70)-\mathrm{Tb}(3)-\mathrm{O}(80) \quad \text { 76.3(3) } \\
& \mathrm{O}(70)-\mathrm{Tb}(3)-\mathrm{O}(80)^{1} \quad 78.9(3) \\
& \mathrm{O}(80)-\mathrm{Tb}(3)-\mathrm{O}(80)^{1} \quad 123.5(4) \\
& \mathrm{O}(70)-\mathrm{Tb}(3)-\mathrm{O}(120)^{1} \quad 77.9(3) \\
& \mathrm{O}(70)-\mathrm{Tb}(3)-\mathrm{O}(120) \quad 72.8(3) \\
& \mathrm{O}(80)-\mathrm{Tb}(3)-\mathrm{O}(120) \quad 117.63(16) \\
& \mathrm{O}(120)^{1}-\mathrm{Tb}(3)-\mathrm{O}(120) \quad 112.1(4) \\
& \mathrm{O}(80)-\mathrm{Tb}(3)-\mathrm{O}(110) \quad 71.9(3) \\
& \mathrm{O}(120)-\mathrm{Tb}(3)-\mathrm{O}(110) \quad 69.9(3) \\
& \mathrm{O}(70)-\mathrm{Tb}(3)-\mathrm{O}(110)^{1} \quad 117.88(15) \\
& \mathrm{O}(80)-\mathrm{Tb}(3)-\mathrm{O}(110)^{1} \quad 76.5(3) \\
& \mathrm{O}(120)-\mathrm{Tb}(3)-\mathrm{O}(110)^{1} \quad 72.6(3) \\
& \mathrm{O}(110)-\mathrm{Tb}(3)-\mathrm{O}(110)^{1} \quad \text { 109.7(4) } \\
& \mathrm{O}(70)-\mathrm{Tb}(3)-\mathrm{O}(3)^{1} \quad 131.1(2) \\
& \mathrm{O}(80)-\mathrm{Tb}(3)-\mathrm{O}(3)^{1} \quad 72.1(2) \\
& \mathrm{O}(120)-\mathrm{Tb}(3)-\mathrm{O}(3)^{1} \quad 155.80(19) \\
& \mathrm{O}(110)-\mathrm{Tb}(3)-\mathrm{O}(3)^{1} \quad 133.1(2) \\
& \mathrm{O}(70)-\mathrm{Tb}(3)-\mathrm{O}(3) \quad \text { 82.87(19) } \\
& \mathrm{O}(80)-\mathrm{Tb}(3)-\mathrm{O}(3) \quad 149.96(18)
\end{aligned}
$$




$\begin{array}{lc}\mathrm{O}(120)-\mathrm{Tb}(3)-\mathrm{O}(3) & 75.3(2) \\ \mathrm{O}(110)-\mathrm{Tb}(3)-\mathrm{O}(3) & 89.7(2) \\ \mathrm{O}(3)^{1}-\mathrm{Tb}(3)-\mathrm{O}(3) & 107.81(12) \\ \mathrm{O}(70)-\mathrm{Tb}(3)-\mathrm{O}(2)^{1} & 151.6(2) \\ \mathrm{O}(80)-\mathrm{Tb}(3)-\mathrm{O}(2)^{1} & 132.1(2) \\ \mathrm{O}(120)-\mathrm{Tb}(3)-\mathrm{O}(2)^{1} & 90.71(18) \\ \mathrm{O}(110)-\mathrm{Tb}(3)-\mathrm{O}(2)^{1} & 155.6(2) \\ \mathrm{O}(3)-\mathrm{Tb}(3)-\mathrm{O}(2)^{1} & 70.43(8) \\ \mathrm{O}(70)-\mathrm{Tb}(3)-\mathrm{O}(2) & 69.91(19) \\ \mathrm{O}(80)-\mathrm{Tb}(3)-\mathrm{O}(2) & 83.70(18) \\ \mathrm{O}(120)-\mathrm{Tb}(3)-\mathrm{O}(2) & 130.4(2) \\ \mathrm{O}(110)-\mathrm{Tb}(3)-\mathrm{O}(2) & 76.8(2) \\ \mathrm{O}(3)-\mathrm{Tb}(3)-\mathrm{O}(2) & 68.78(8) \\ \mathrm{O}(2)^{1}-\mathrm{Tb}(3)-\mathrm{O}(2) & 107.47(12) \\ \mathrm{Tb}(2)-\mathrm{O}(1)-\mathrm{Tb}(2)^{1} & 160.52(17) \\ \mathrm{Tb}(2)-\mathrm{O}(1)-\mathrm{Tb}(1)^{1} & 88.53(3) \\ \mathrm{Tb}(2)-\mathrm{O}(1)-\mathrm{Tb}(1) & 88.10(3) \\ \mathrm{Tb}(1)^{1}-\mathrm{O}(1)-\mathrm{Tb}(1) & 159.98(16) \\ \mathrm{Tb}(2)-\mathrm{O}(2)-\mathrm{Tb}(1) & 99.23(10) \\ \mathrm{Tb}(2)-\mathrm{O}(2)-\mathrm{Tb}(3) & 108.15(9) \\ \mathrm{Tb}(1)-\mathrm{O}(2)-\mathrm{Tb}(3) & 109.07(9) \\ \mathrm{Tb}(1)-\mathrm{O}(3)-\mathrm{Tb}(2)^{1} & 98.79(10) \\ \mathrm{Tb}(1)-\mathrm{O}(3)-\mathrm{Tb}(3) & 110.29(9) \\ \mathrm{Tb}(2)^{1}-\mathrm{O}(3)-\mathrm{Tb}(3) & 107.38(9) \\ \mathrm{Tb}(2)-\mathrm{O}(100)-\mathrm{Tb}(1) 1 & 95.40(9)\end{array}$

Symmetry transformations used to generate equivalent atoms: ${ }^{1}-\mathrm{x}, \mathrm{y},-\mathrm{z}+1 / 2$

Selected bond lengths $[\AA]$ and angles $\left[^{\circ}\right]$ for $\left[\mathrm{Ho}_{5}(\mathrm{OH})_{5}(\mathbf{a b z m})_{10}\right] \cdot 4$ Toluene.

\begin{tabular}{ll}
\hline $\mathrm{Ho}(1)-\mathrm{O}(50)$ & $2.265(2)$ \\
$\mathrm{Ho}(1)-\mathrm{O}(60)$ & $2.279(2)$ \\
$\mathrm{Ho}(1)-\mathrm{O}(3)$ & $2.308(2)$ \\
$\mathrm{Ho}(1)-\mathrm{O}(40)$ & $2.318(2)$
\end{tabular}




\begin{tabular}{|c|c|}
\hline $\mathrm{Ho}(1)-\mathrm{O}(2)$ & $2.324(2)$ \\
\hline $\mathrm{Ho}(1)-\mathrm{O}(30)$ & $2.362(2)$ \\
\hline $\mathrm{Ho}(1)-\mathrm{O}(100)^{1}$ & $2.430(2)$ \\
\hline $\mathrm{Ho}(1)-\mathrm{O}(1)$ & $2.5779(5)$ \\
\hline Ho(1)..Ho(2) & $3.51086(19)$ \\
\hline $\operatorname{Ho}(1) . . \operatorname{Ho}(2)^{1}$ & $3.53528(18)$ \\
\hline $\mathrm{Ho}(1) . . \mathrm{Ho}(3)$ & $3.85716(19)$ \\
\hline $\mathrm{Ho}(2)-\mathrm{O}(10)$ & $2.263(2)$ \\
\hline $\mathrm{Ho}(2)-\mathrm{O}(20)$ & $2.279(2)$ \\
\hline $\mathrm{Ho}(2)-\mathrm{O}(2)$ & $2.297(2)$ \\
\hline $\mathrm{Ho}(2)-\mathrm{O}(90)$ & $2.313(2)$ \\
\hline $\mathrm{Ho}(2)-\mathrm{O}(3)^{1}$ & $2.339(2)$ \\
\hline $\mathrm{Ho}(2)-\mathrm{O}(100)$ & $2.347(2)$ \\
\hline $\mathrm{Ho}(2)-\mathrm{O}(40)$ & $2.436(2)$ \\
\hline $\mathrm{Ho}(2)-\mathrm{O}(1)$ & $2.4760(5)$ \\
\hline $\operatorname{Ho}(2) \ldots \mathrm{Ho}(3)$ & $3.8198(2)$ \\
\hline $\mathrm{Ho}(3)-\mathrm{O}(70)$ & $2.275(7)$ \\
\hline $\mathrm{Ho}(3)-\mathrm{O}(80)$ & $2.302(6)$ \\
\hline $\mathrm{Ho}(3)-\mathrm{O}(110)$ & $2.323(8)$ \\
\hline $\mathrm{Ho}(3)-\mathrm{O}(120)$ & $2.334(7)$ \\
\hline $\mathrm{Ho}(3)-\mathrm{O}(3)$ & $2.384(2)$ \\
\hline $\mathrm{Ho}(3)-\mathrm{O}(2)$ & $2.416(2)$ \\
\hline $\mathrm{O}(50)-\mathrm{Ho}(1)-\mathrm{O}(60)$ & $74.41(8)$ \\
\hline $\mathrm{O}(50)-\mathrm{Ho}(1)-\mathrm{O}(3)$ & $75.98(7)$ \\
\hline $\mathrm{O}(60)-\mathrm{Ho}(1)-\mathrm{O}(3)$ & $140.25(8)$ \\
\hline $\mathrm{O}(50)-\mathrm{Ho}(1)-\mathrm{O}(40)$ & $152.97(8)$ \\
\hline $\mathrm{O}(60)-\mathrm{Ho}(1)-\mathrm{O}(40)$ & $81.24(8)$ \\
\hline $\mathrm{O}(3)-\mathrm{Ho}(1)-\mathrm{O}(40)$ & $131.05(7)$ \\
\hline $\mathrm{O}(50)-\mathrm{Ho}(1)-\mathrm{O}(2)$ & $114.50(8)$ \\
\hline $\mathrm{O}(60)-\mathrm{Ho}(1)-\mathrm{O}(2)$ & $146.13(8)$ \\
\hline $\mathrm{O}(3)-\mathrm{Ho}(1)-\mathrm{O}(2)$ & $71.46(7)$ \\
\hline $\mathrm{O}(40)-\mathrm{Ho}(1)-\mathrm{O}(2)$ & $80.12(8)$ \\
\hline $\mathrm{O}(50)-\mathrm{Ho}(1)-\mathrm{O}(30)$ & $89.05(8)$ \\
\hline
\end{tabular}




\begin{tabular}{|c|c|}
\hline$(60)-\mathrm{Ho}(1)-\mathrm{O}(30)$ & $76.10(8)$ \\
\hline $\mathrm{O}(3)-\mathrm{Ho}(1)-\mathrm{O}(30)$ & $129.22(8)$ \\
\hline $\mathrm{O}(40)-\mathrm{Ho}(1)-\mathrm{O}(30)$ & $73.65(8)$ \\
\hline $\mathrm{O}(2)-\mathrm{Ho}(1)-\mathrm{O}(30)$ & $71.64(7)$ \\
\hline $\mathrm{O}(50)-\mathrm{Ho}(1)-\mathrm{O}(100)^{1}$ & $91.82(8)$ \\
\hline $\mathrm{O}(60)-\mathrm{Ho}(1)-\mathrm{O}(100)^{1}$ & $77.95(8)$ \\
\hline $\mathrm{O}(3)-\mathrm{Ho}(1)-\mathrm{O}(100)^{1}$ & $77.10(7)$ \\
\hline $\mathrm{O}(40)-\mathrm{Ho}(1)-\mathrm{O}(100)^{1}$ & $94.45(7)$ \\
\hline $\mathrm{O}(2)-\mathrm{Ho}(1)-\mathrm{O}(100)^{1}$ & $131.46(7)$ \\
\hline $\mathrm{O}(30)-\mathrm{Ho}(1)-\mathrm{O}(100)^{1}$ & $152.78(8)$ \\
\hline $\mathrm{O}(50)-\mathrm{Ho}(1)-\mathrm{O}(1)$ & $140.38(6)$ \\
\hline $\mathrm{O}(60)-\mathrm{Ho}(1)-\mathrm{O}(1)$ & 127.61(9) \\
\hline $\mathrm{O}(3)-\mathrm{Ho}(1)-\mathrm{O}(1)$ & $67.27(7)$ \\
\hline $\mathrm{O}(40)-\mathrm{Ho}(1)-\mathrm{O}(1)$ & $65.27(6)$ \\
\hline $\mathrm{O}(2)-\mathrm{Ho}(1)-\mathrm{O}(1)$ & $67.57(7)$ \\
\hline $\mathrm{O}(30)-\mathrm{Ho}(1)-\mathrm{O}(1)$ & $125.56(6)$ \\
\hline $\mathrm{O}(100)^{1-}$ & $66.53(6)$ \\
\hline $\mathrm{O}(10)-\mathrm{Ho}(2)-\mathrm{O}(20)$ & $75.11(8)$ \\
\hline $\mathrm{O}(10)-\mathrm{Ho}(2)-\mathrm{O}(2)$ & $74.98(8)$ \\
\hline $\mathrm{O}(20)-\mathrm{Ho}(2)-\mathrm{O}(2)$ & $138.07(7)$ \\
\hline $\mathrm{O}(10)-\mathrm{Ho}(2)-\mathrm{O}(90)$ & $81.26(9)$ \\
\hline $\mathrm{O}(20)-\mathrm{Ho}(2)-\mathrm{O}(90)$ & $78.27(8)$ \\
\hline $\mathrm{O}(2)-\mathrm{Ho}(2)-\mathrm{O}(90)$ & $124.72(8)$ \\
\hline $\mathrm{O}(10)-\mathrm{Ho}(2)-\mathrm{O}(3)^{1}$ & $114.02(8)$ \\
\hline $\mathrm{O}(20)-\mathrm{Ho}(2)-\mathrm{O}(3)^{1}$ & $147.30(7)$ \\
\hline $\mathrm{O}(2)-\mathrm{Ho}(2)-\mathrm{O}(3)^{1}$ & $72.96(7)$ \\
\hline $\mathrm{O}(90)-\mathrm{Ho}(2)-\mathrm{O}(3)^{1}$ & $72.65(8)$ \\
\hline $\mathrm{O}(10)-\mathrm{Ho}(2)-\mathrm{O}(100)$ & $148.10(8)$ \\
\hline $\mathrm{O}(20)-\mathrm{Ho}(2)-\mathrm{O}(100)$ & 79.93(7) \\
\hline $\mathrm{O}(2)-\mathrm{Ho}(2)-\mathrm{O}(100)$ & $136.28(7)$ \\
\hline $\mathrm{O}(90)-\mathrm{Ho}(2)-\mathrm{O}(100)$ & $74.41(8)$ \\
\hline $\mathrm{O}(3)^{1}-\mathrm{Ho}(2)-\mathrm{O}(100)$ & $78.16(7)$ \\
\hline $\mathrm{O}(10)-\mathrm{Ho}(2)-\mathrm{O}(40)$ & $94.31(8)$ \\
\hline $\mathrm{O}(20)-\mathrm{Ho}(2)-\mathrm{O}(40)$ & $75.43(8)$ \\
\hline
\end{tabular}




\begin{tabular}{|c|c|}
\hline $\mathrm{O}(2)-\mathrm{Ho}(2)-\mathrm{O}(40)$ & $78.23(7)$ \\
\hline $\mathrm{O}(90)-\mathrm{Ho}(2)-\mathrm{O}(40)$ & $153.58(8)$ \\
\hline $\mathrm{O}(3) \# 1-\mathrm{Ho}(2)-\mathrm{O}(40)$ & $131.64(7)$ \\
\hline $\mathrm{O}(100)-\mathrm{Ho}(2)-\mathrm{O}(40)$ & $98.35(7)$ \\
\hline $\mathrm{O}(10)-\mathrm{Ho}(2)-\mathrm{O}(1)$ & $142.00(7)$ \\
\hline $\mathrm{O}(20)-\mathrm{Ho}(2)-\mathrm{O}(1)$ & 124.61(9) \\
\hline $\mathrm{O}(2)-\mathrm{Ho}(2)-\mathrm{O}(1)$ & $69.77(7)$ \\
\hline $\mathrm{O}(90)-\mathrm{Ho}(2)-\mathrm{O}(1)$ & $131.08(6)$ \\
\hline $\mathrm{O}(3)^{1}-\mathrm{Ho}(2)-\mathrm{O}(1)$ & $68.61(7)$ \\
\hline $\mathrm{O}(100)-\mathrm{Ho}(2)-\mathrm{O}(1)$ & $69.44(6)$ \\
\hline $\mathrm{O}(40)-\mathrm{Ho}(2)-\mathrm{O}(1)$ & $65.28(6)$ \\
\hline $\mathrm{O}(70)-\mathrm{Ho}(3)-\mathrm{O}(70)^{1}$ & $119.3(4)$ \\
\hline $\mathrm{O}(70)-\mathrm{Ho}(3)-\mathrm{O}(80)$ & $75.0(3)$ \\
\hline $\mathrm{O}(70)^{1}-\mathrm{Ho}(3)-\mathrm{O}(80)$ & $77.7(3)$ \\
\hline $\mathrm{O}(80)^{1}-\mathrm{Ho}(3)-\mathrm{O}(80)$ & $124.3(3)$ \\
\hline $\mathrm{O}(70)^{1}-\mathrm{Ho}(3)-\mathrm{O}(110)$ & $116.98(12)$ \\
\hline $\mathrm{O}(80)^{1}-\mathrm{Ho}(3)-\mathrm{O}(110)$ & $79.1(3)$ \\
\hline $\mathrm{O}(80)-\mathrm{Ho}(3)-\mathrm{O}(110)$ & $71.7(3)$ \\
\hline $\mathrm{O}(110)-\mathrm{Ho}(3)-\mathrm{O}(110)^{1}$ & $114.7(5)$ \\
\hline $\mathrm{O}(110)-\mathrm{Ho}(3)-\mathrm{O}(120)^{1}$ & $72.6(3)$ \\
\hline $\mathrm{O}(70)-\mathrm{Ho}(3)-\mathrm{O}(120)$ & $71.2(2)$ \\
\hline $\mathrm{O}(70)^{1}-\mathrm{Ho}(3)-\mathrm{O}(120)$ & $76.0(3)$ \\
\hline $\mathrm{O}(80)-\mathrm{Ho}(3)-\mathrm{O}(120)$ & $117.92(14)$ \\
\hline $\mathrm{O}(110)-\mathrm{Ho}(3)-\mathrm{O}(120)$ & $72.3(3)$ \\
\hline $\mathrm{O}(120)^{1}-\mathrm{Ho}(3)-\mathrm{O}(120)$ & $111.9(3)$ \\
\hline $\mathrm{O}(70)-\mathrm{Ho}(3)-\mathrm{O}(3)$ & $85.4(2)$ \\
\hline $\mathrm{O}(80)-\mathrm{Ho}(3)-\mathrm{O}(3)$ & $149.14(14)$ \\
\hline $\mathrm{O}(110)-\mathrm{Ho}(3)-\mathrm{O}(3)$ & $88.8(2)$ \\
\hline $\mathrm{O}(120)-\mathrm{Ho}(3)-\mathrm{O}(3)$ & $76.06(17)$ \\
\hline $\mathrm{O}(70)-\mathrm{Ho}(3)-\mathrm{O}(3)^{1}$ & $133.1(2)$ \\
\hline $\mathrm{O}(80)-\mathrm{Ho}(3)-\mathrm{O}(3)^{1}$ & $72.43(16)$ \\
\hline $\mathrm{O}(110)-\mathrm{Ho}(3)-\mathrm{O}(3)^{1}$ & $131.6(2)$ \\
\hline $\mathrm{O}(120)-\mathrm{Ho}(3)-\mathrm{O}(3)^{1}$ & $155.32(15)$ \\
\hline $\mathrm{O}(3)-\mathrm{Ho}(3)-\mathrm{O}(3)^{1}$ & $106.83(10)$ \\
\hline
\end{tabular}




$$
\begin{array}{lc}
\mathrm{O}(70)-\mathrm{Ho}(3)-\mathrm{O}(2) 1 & 152.4(2) \\
\mathrm{O}(80)-\mathrm{Ho}(3)-\mathrm{O}(2) 1 & 132.56(16) \\
\mathrm{O}(120)-\mathrm{Ho}(3)-\mathrm{O}(2) 1 & 90.35(13) \\
\mathrm{O}(3)-\mathrm{Ho}(3)-\mathrm{O}(2)^{1} & 70.10(7) \\
\mathrm{O}(70)-\mathrm{Ho}(3)-\mathrm{O}(2) & 73.2(2) \\
\mathrm{O}(80)-\mathrm{Ho}(3)-\mathrm{O}(2) & 82.88(13) \\
\mathrm{O}(110)-\mathrm{Ho}(3)-\mathrm{O}(2) & 74.2(2) \\
\mathrm{O}(110)^{1}-\mathrm{Ho}(3)-\mathrm{O}(2) & 155.6(2) \\
\mathrm{O}(120)-\mathrm{Ho}(3)-\mathrm{O}(2) & 131.05(17) \\
\mathrm{O}(3)-\mathrm{Ho}(3)-\mathrm{O}(2) & 68.61(7) \\
\mathrm{O}(2)^{1}-\mathrm{Ho}(3)-\mathrm{O}(2) & 107.47(10) \\
\mathrm{Ho}(2)^{1}-\mathrm{O}(1)-\mathrm{Ho}(2) & 160.93(13) \\
\mathrm{Ho}(2)-\mathrm{O}(1)-\mathrm{Ho}(1) & 87.98(2) \\
\mathrm{Ho}(2)-\mathrm{O}(1)-\mathrm{Ho}(1)^{1} & 88.75(2) \\
\mathrm{Ho}(1)-\mathrm{O}(1)-\mathrm{Ho}(1)^{1} & 160.16(12) \\
\mathrm{Ho}(2)-\mathrm{O}(2)-\mathrm{Ho}(1) & 98.88(8) \\
\mathrm{Ho}(2)-\mathrm{O}(2)-\mathrm{Ho}(3) & 108.25(7) \\
\mathrm{Ho}(1)-\mathrm{O}(2)-\mathrm{Ho}(3) & 108.91(8) \\
\mathrm{Ho}(1)-\mathrm{O}(3)-\mathrm{Ho}(2)^{1} & 99.06(8) \\
\mathrm{Ho}(1)-\mathrm{O}(3)-\mathrm{Ho}(3) & 110.58(8) \\
\mathrm{Ho}(2)^{1}-\mathrm{O}(3)-\mathrm{Ho}(3) & 107.97(7)
\end{array}
$$

Symmetry transformations used to generate equivalent atoms: ${ }^{1}-\mathrm{x}, \mathrm{y},-\mathrm{z}+1 / 2$ 
Raman spectrum of the abzmH ligand

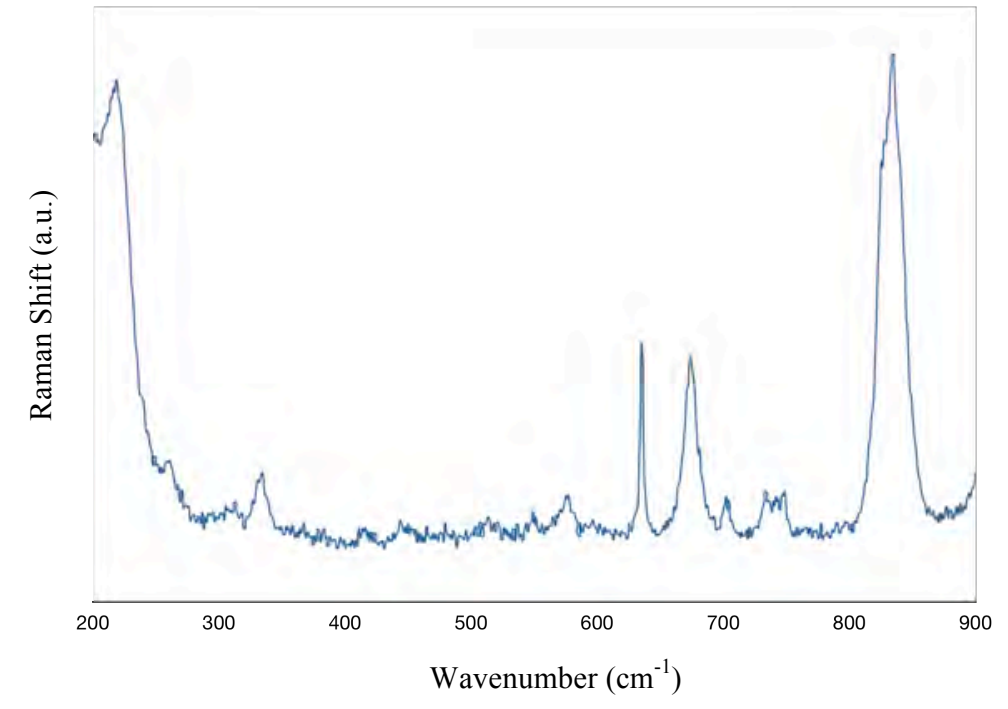

